\title{
TESTING AND RATING HAND.
}

FIRED HOT-WATER-SUPPLY

\section{BOILERS}

\section{helerence hook not to be taken from the Library.}

\section{COMIMERCIAL STANDARD CS145-47}

(Issued November 26, 1947)

Effective Date for New Production From December 1, 1948

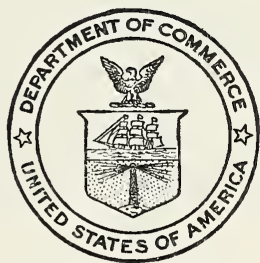

A RECORDED VOLUNTARY STANDARD

OF THE TRADE

\section{UNITED STATES DEPARTMENT OF COMMERCE}

W. AVERELL HARRIMAN, Secretary 


\section{COMMODITY STANDARDS}

Simplified Practice Recommendations and Commercial Standards are developed by manufacturers, distributors, and users in cooperation with the Commodity Standards Division ${ }^{1}$ of the National Bureau of Standards. The purpose of Simplified Practice Recommendations is to eliminate avoidable waste through the establishment of standards of practice for stock sizes and varieties of specific commodities that currently are in general production and demand. The purpose of Commercial Standards is to establish standard methods of test, rating, certification, and labeling of commodities, and to provide uniform bases for fair competition.

The adoption and use of a Simplified Practice Recommendation or Commercial Standard is voluntary. However, when reference to a Commercial Standard is made in contracts, labels, invoices, or advertising literature, the provisions of the standard are enforceable through usual legal channels as a part of the sales contract.

A Simplified Practice Recommendation or Commercial Standard originates with the proponent industry. The sponsors may be manufacturers, distributors, or users of the specific product. One of these three elements of industry submits to the Commodity Standards Division the necessary data to be used as the basis for developing a standard of practice. The Division, by means of assembled conferences or letter referenda, or both, assists the sponsor group in arriving at a tentative standard of practice and thereafter refers it to the other elements of the same industry for approval or for constructive criticism that will be helpful in making any necessary adjustments. The regular procedure of the Division assures continuous servicing of each effective Simplified Practice Recommendation and Commercial Standard, through review and revision, whenever, in the opinion of the industry, changing conditions warrant such action. Simplified Practice Recommendations and Commercial Standards are printed and made available by the Department of Commerce, through the Government Printing Office.

\section{COMMERCIAL STANDARD FOR TESTING AND RATING HAND-FIRED HOT-WATER-SUPPLY BOILERS}

On December 4, 1942, at the instance of the Federal Housing Administration, a general conference of representative manufacturers, distributors, and users of hand-fired hot-water-supply boilers adopted a recommended commercial standard for this commodity.

Composite recommendations based on the results of further laboratory investigations reported by the Anthracite Industries Laboratory and the Institute of Boiler and Radiator Manufacturers, and on comment received following circulation of recommended drafts of the standard to manufacturers, distributors, and users, on three separate occasions, resulted in a draft which was circulated on December 26,1946 , to the trade for written acceptance.

The trade has since approved the standard as shown herein for issuance by the United States Department of Commerce.

Project Manager: F. E. Powell, assisted by P. S. Murphy, Commodity Standards Division, National Bureau of Standards.

Technical Advisers: R. S. Dill and P. R. Achenbach, Building Technology

Division, National Bureau of Standards.

1 Effective July 1, 1947, the Division of Simplified Practice, organized in 1921, and the Division of Trade Standards, organized in 1927, were combined to form the Commodity Standards Division. Since their organization, both of these Divisions have assisted many industries in the development of Simplified Practice Recommendations and Commercial Standards for a wide variety of commodities. A list of previously established Commercial Standards appears herein. A list of effective Simplified Practice Recommendations may be obtained from the Commodity Standards Division. National Bureau of Standards, Washington 25, D. C. 
for

\section{TESTING AND RATING HAND-FIRED HOT-WATER- SUPPLY BOILERS}

\section{PURPOSE}

1. The purpose of this standard is to provide a uniform method of testing and rating the performance of hand-fired hot-water-supply boilers as a basis for fair competition among manufacturers, and to eliminate confusion among sellers and buyers as to the significance of published ratings.

\section{SCOPE}

2. This standard applies to all sizes of hand-fired, solid-fuel-burning hot-water-supply boilers, except those of the magazine-feed type and laundry type, and consists of the following sections:

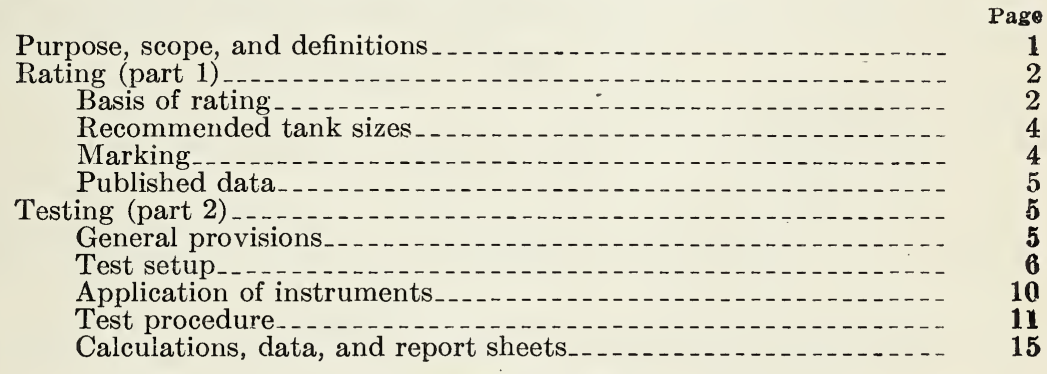

\section{DEFINITIONS}

3. Ashpit cleanings comprise the substance removed from the ashpit before dumping the residue remaining on the grate.

4. Ashpit draft damper is a damper used to control the admission of air to the ashpit.

5. Available fuel charge is the charge of fuel actually used to develop the maximum output, fired at one time, upon a kindling-fuel bed of sufficient depth to ignite this charge properly. Btu.

6. Calorific value (coal) is the heat value per pound of dry fuel in

7. Capacity is the equivalent of the maximum output when expressed in gallons of water heated $100^{\circ} \mathrm{F}$ in 3 hours.

8. Check damper is a device for admitting air to the smoke hood, stack connection, or stack.

9. Chimney height.-See Stack height.

10. Choke damper is a damper placed within the gas passage for regulating the flow of gases. 
11. Clinker is the weight of clinkers that are removed through the fire or clinker doors at the end of each charge.

12. Damper is a device used to control the flow of air or other gases.

13. Draft regulator is a device for controlling the draft in the boiler.

14. Fuel capacity is the weight of fuel in pounds that can be placed on the bare grate, leaving sufficient space above the fuel for proper combustion.

15. Grate area, as used in this commercial standard, shall be the horizontal plane area of the firebox in square feet at the highest point of the grate bars.

16. Maximum output is the average of two or more maximum output tests in terms of Btu per hour under the conditions and limitations stipulated in this commercial standard.

17. Minimum horizontal combustion area is the minimum horizontal area of the fuel bed in square inches between the highest point of the grate and the sill of the firedoor.

18. Output rate is the output developed under test in terms of Btu for a given time period under the conditions and limitations stipulated by this commercial standard.

19. Rating is the maximum output in Btu per hour, and the capacity in gallons of water heated $100^{\circ} \mathrm{F}$ in 3 hours.

20. Secondary air damper is a damper used to control the admission of air to the gases of combustion for the purpose of aiding combustion.

21. Smoke hood is a device which conducts the flue gases from the boiler to the stack connection.

22. Stack height is the vertical distance from the grate level to the top of the stack.

23. Time limit is the time the available fuel charge will last when burned under the conditions specified for obtaining the maximum output.

24. Total residue is the sum of the weights of the ashpit cleanings, the clinkers, and the residue left on the grates at the end of the test.

\section{Part 1.-RATING OF HAND-FIRED HOT-WATER- SUPPLY BOILERS}

\section{BASIS OF RATING}

25. Determination of rating.-The provisions of this part 1 specify the method and procedure for determining the maximum output in Btu per hour, and the capacity in gallons of water heated $100^{\circ} \mathrm{F}$ in 3 hours, of hot-water supply boilers, except boilers of the magazine-feed type and laundry type.

26. Method of rating.

26a. Maximum output.-The maximum output in Btu per hour, based on a minimum firing period of 6 hours, shall be the average of two or more maximum output tests conducted in accordance with the procedure outlined in part 2-Testing of Hand-Fired Hot-WaterSupply Boilers. The gross $\mathrm{I}=\mathrm{B}=\mathrm{R}$ output of a heating boiler determined in accordance with the provisions of part 2 of the $I=B=R$ Testing and Rating Code for Low Pressure Heating Boilers may be used as the maximum output of a hot-water supply boiler, which is 
identical except for thickness of metal. When the maximum output and capacity are determined in accordance with the provisions of this commercial standard, the following limiting factors shall apply:

(1) Number of boilers to be tested.-A test shall be conducted on every size of hot-water-supply boiler, except that it is necessary to test only the shortest and longest sizes of a series of boilers wherein the increase in size is obtained by the addition of intermediate sections. Ratings for untested intermediate sizes shall be determined by interpolating evenly between ratings of tested sizes.

(2) Height of chimney for maximum output test.-The height of the chimney selected for the maximum output test shall not exceed the height shown in figure 1.
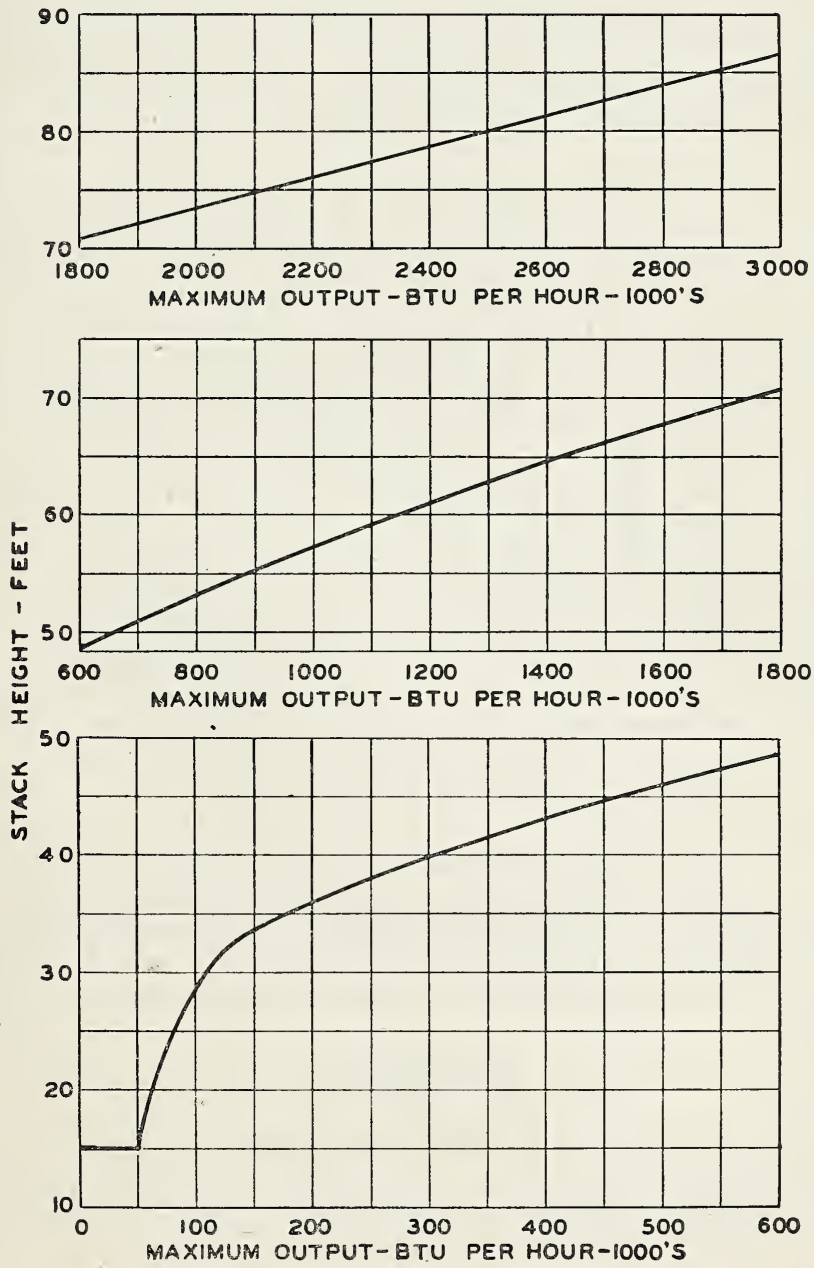

FIgURE 1. Maximum stack-height curve. 
26b. Output rate obtained in banking test.-The output rate obtained in the last 2 hours of the banking test, as prescribed in part 2 of this commercial standard, for boilers with horizontal combustion area below the firedoor sill of less than 125 square inches shall not exceed 15 percent of the maximum output.

26c. Rating designations.- The rating shall be expressed as the maximum output in Btu per hour and as the capacity in gallons of water heated $100^{\circ} \mathrm{F}$ in 3 hours. The maximum output shall be adjusted to the nearest 1,000 Btu and the capacity to the nearest gallon. The capacity shall be determined by the following formula:

$$
\text { Capacity }=\frac{\text { Maximum output }}{278} \text {. }
$$

27. Selection of boilers for fuels of less than 13,000 Btu/lb heating value.-When selecting hot-water-supply boilers for burning fuel of lower heating value than 13,000 Btu per pound (dry), correction factors obtained from figure 2 shall be used.

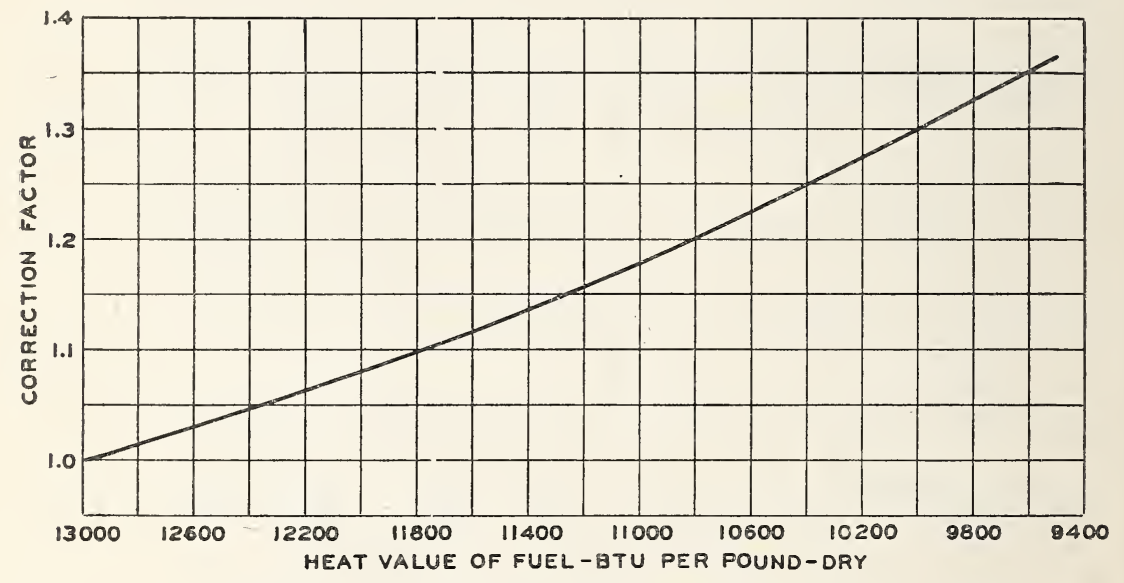

FigdRe 2. Correction factor-heat value curve.

\section{RECOMMENDED TANK SIZES}

28. For each boiler rated in accordance with this commercial standard, a tank shall be recommended whose internal volume in gallons is not less than the numerical equivalent of the capacity as defined in paragraph 7.

\section{MARKING}

29. Minimum data to be shown on boilers shall consist of:

(a) Boiler number.

(b) Capacity-gallons of water heated $100^{\circ} \mathrm{F}$ in 3 hours. 


\section{PUBLISHED DATA}

30. Minimum data to be shown in trade literature shall consist of:

(a) Boiler number.

(b) Maximum output-Btu per hour.

(c) Capacity-gallons of water heated $100^{\circ} \mathrm{F}$ in 3 hours.

(d) Recommended tank size.

\section{Part 2.-TESTING OF HAND-FIRED HOT-WATER- SUPPLY BOILERS}

\section{GENERAL PROVISIONS}

31. Type of boilers.-The provisions of this part 2 specify the method for testing hand-fired hot-water-supply boilers to determine performance characteristics. They apply only to boilers with substantially horizontal grates and are not applicable to boilers of the magazine-feed type or the laundry type.

32. Boiler assembly. - The boiler shall be a stock boiler assembled in accordance with the manufacturer's directions, with all joints and openings sealed as specified by the manufacturer.

33. Chimneys.- Tests may be conducted with either natural or induced draft with means provided for controlling draft in accordance with paragraphs 53 and 58 .

34. Covering.-Tests may be conducted under one of the following two conditions with respect to jackets:

(a) If a jacket is cataloged for the boiler, this jacket should be in place during the test.

(b) If the jacket is unavailable, or if no jacket is cataloged, all parts of the boiler which would normally be insulated may be covered with 1 inch of asbestos, provided that no insulation shall be used in testing boilers for which no jacket is cataloged and where the minimum horizontal combustion area below the firedoor sill is less than 250 square inches.

No credit may be taken for heat loss from the boiler. The smoke hood and stack connection shall be insulated as specified in paragraph 40.

35. Output.- The output of boilers shall be determined by measuring the amount of water flowing through the boiler and measuring the temperature rise as prescribed in paragraphs 39 and 55 .

36. Fuel specifications.-The fuel shall meet the following specifications:

Volatile matter: Not less than 4 percent nor greater than 6 percent dry basis.

Ash content: Not less than 8 percent nor greater than 12 percent dry basis.

Calorific value: Not less than 13,200 Btu per pound nor greater than 13,800 Btu per pound dry basis.

Softening temperature of the ash: $2,700^{\circ} \mathrm{F}$ or higher.

Moisture content: Not greater than 5 percent as fired. 
36a. Sizes of fuel used shall be as follows:

Chestnut coal shall be used in testing boilers with minimum horizontal combustion area below the firedoor sill of less than 250 square inches. Stove size shall be used in testing all other boilers unless a different size is specified by the manufacturer. Test fuel is to be obtained from the Anthracite Institute, Wilkes-Barre, Pa. This one source is specified in the interest of having a uniform quality fuel for these tests.

36b. The commercial sizes of anthracite coal for hand-fired domestic use are listed by the Anthracite Committee of the Production Control Plan for the Anthracite Industry, Harrisburg, Pa., as follows:

\section{ROUND MESH}

Size

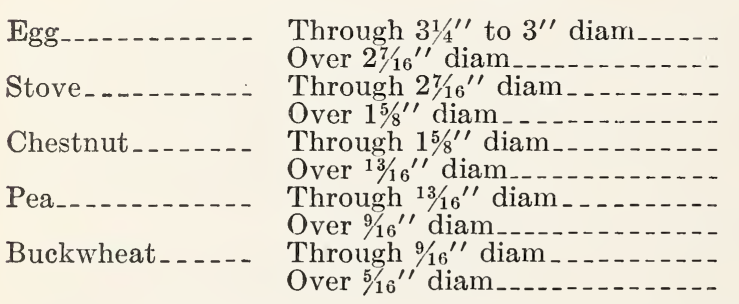

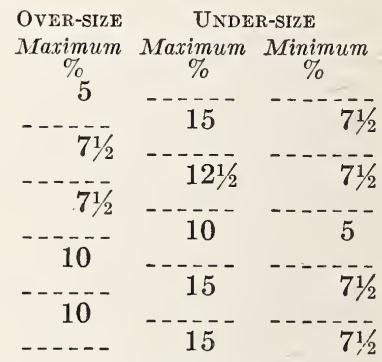

36c. Storage of fuel shall be in a dry place to minimize variations in moisture content.

37. Fuel analysis.-A representative sample of the fuel shall be obtained in accordance with the Standard Method of Sampling Coal for Analysis (ASTM Designation: D21-40, or latest revision) of the American Society for Testing Materials. The fuel analysis shall be made by a reliable laboratory in accordance with the Standard Methods of Laboratory Sampling and Analysis of Coal and Coke (ASTM Designation: D271-44, or latest revision) of the American Society for Testing Materials. When determining volatile matter in accordance with this method, the procedure shall be modified, if necessary, in accordance with paragraphs $14 \mathrm{~b}$ and $14 \mathrm{c}$ of ASTM Designation: D271-44.

38. Instruments.-The instruments used shall include:

(a) Means to measure temperature of stack gases, feed and outlet water.

(b) An Orsat or equivalent instrument to draw and analyze gas samples from the stack connection.

(c) Draft gages to measure draft in stack connection and ashpit.

(d) Scales for weighing the fuel, ash, clinker, and residue.

(e) Means to measure the flow of water through the boiler as prescribed in paragraph 39.

\section{TEST SETUP}

39. Water-supply tank and piping.

39a. A typical test setup for hot-water-supply boiler tests is shown diagrammatically in figure 3 . The purpose of this test setup is to provide a steady water flow through the boiler, obtained by drawing 
the water from an overflow tank that gives a constant head. The overflow tank is partitioned into two sections, into the smaller one of which water is fed from a suitable supply, such as city water. The supply rate shall be set higher than the rate of flow through the boiler so that there is a continuous overflow through the drain. The water which flows to the boiler is drawn from the larger section of the tank so that the partition prevents the incoming supply water from disturbing the flow to the boiler.
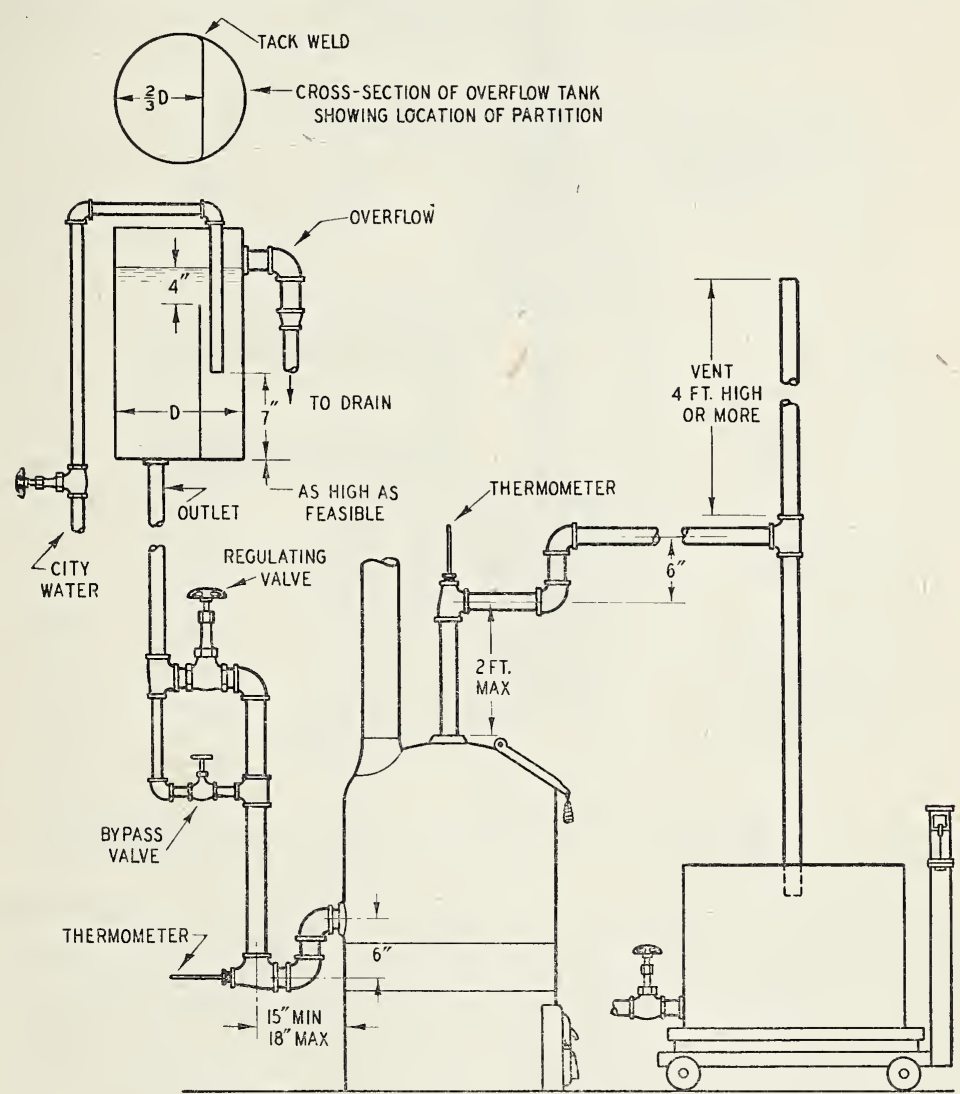

Frgure 3. Typical test setup and piping.

Nоте 1.-I Jimensions of overflow tank suitable for flows up to 3,000 1b/hr: Diameter, $14 \mathrm{in}$., height, $30 \mathrm{in}$. NOTE 2.-Piping shall be insulated between boiler and a point 4 in. beyond thermometers.

39b. Fittings. - The size of the connecting pipe from the overflow tank to the boiler depends on the height of the tank above the boilerthe greater the height, the smaller the pipe that can be used. A regulating valve is placed in this pipe, and it is recommended that it be bypassed by a smaller line containing a valve, in order to obtain closer regulation. A gate valve with its stem preferably in a vertical position may be used for the main regulating valve, and the use of a needle valve for the bypass is recommended. A thermometer or 769782-48-2 
thermocouple shall be located within 2 feet of the inlet tapping of the boiler, and another thermometer or thermocouple shall be located within 2 feet of the outlet tapping of the boiler. The details of the method of installing the thermometers or thermocouples are shown in figures 3 and 4 . A vent should be provided at the high point of the outlet pipe in order to prevent syphoning.

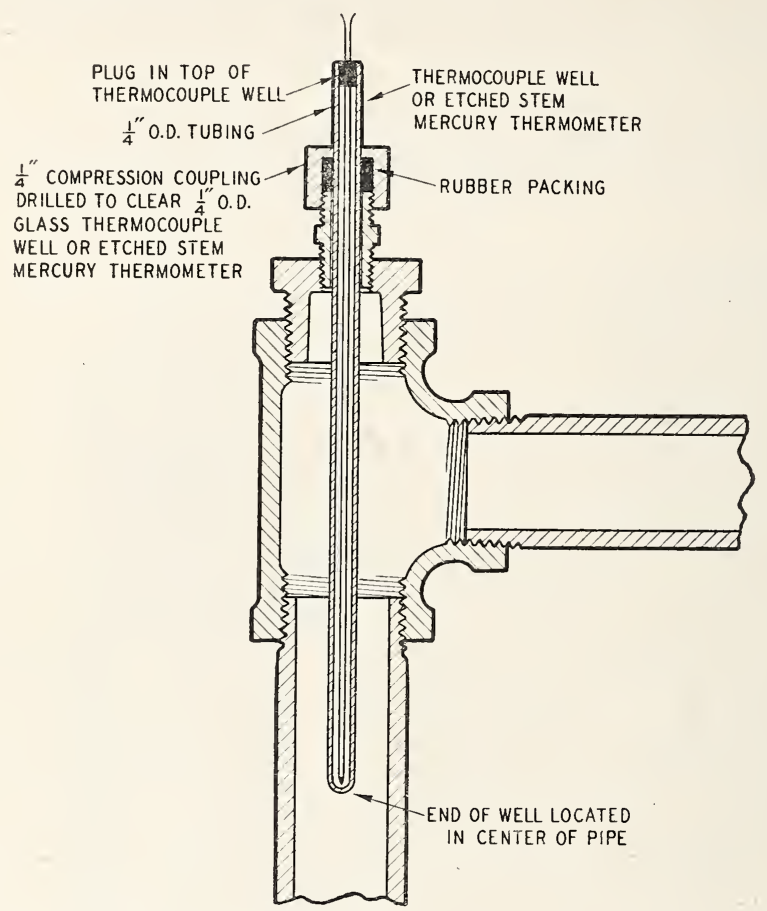

FIGURE 4. Method of installing thermocouple well or thermometer.

39c. This typical setup is recommended but, except for the piping details between the boiler and the points at which the inlet- and outlet-water temperatures are observed, it is not mandatory as any other method may be used, provided that the rate of flow through the boiler does not vary more than \pm 3 percent, as prescribed in paragraph 55 .

$39 \mathrm{~d}$. The dimensions of the overflow tank shown in figure 3 are suitable for flow rates up to approximately 3,000 pounds per hour. For larger flow rates the tank should be correspondingly enlarged.

40. Stack connection.-A vertical stack connection, the full size of the smoke hood or flue gas outlet collar, shall be used. If no vertical outlet is provided, a standard elbow shall be connected directly to the horizontal outlet. The stack connection shall be vertical for at least three pipe diameters. Smoke hood, elbow, and a length equal to at least three pipe diameters of the stack connection shall be insulated with $1 \frac{1 / 2}{2}$ inches of mineral wool, suitable for $1,200^{\circ} \mathrm{F}$ or higher, which must be thoroughly dry before starting the tests. Smoke hood, check damper, and stack connection shall be carefully sealed with boiler cement before the insulation is applied. The 
choke damper, if furnished, shall be in place and open wide during tests, except that it may be closed during the banking test. An auxiliary choke damper shall be placed in the uninsulated portion of the stack connection, and a check damper may be used in the stack below the breeching.

40a. Layout of stack connection.-For boilers with smoke hoods, or rear outlet collars, the general arrangement of the stack connection is shown in figure 5 , while that for boilers with a flue outlet collar on top is shown in figure 6 . The additional choke damper and draft tube required for the banking test are also shown in figure 6 .

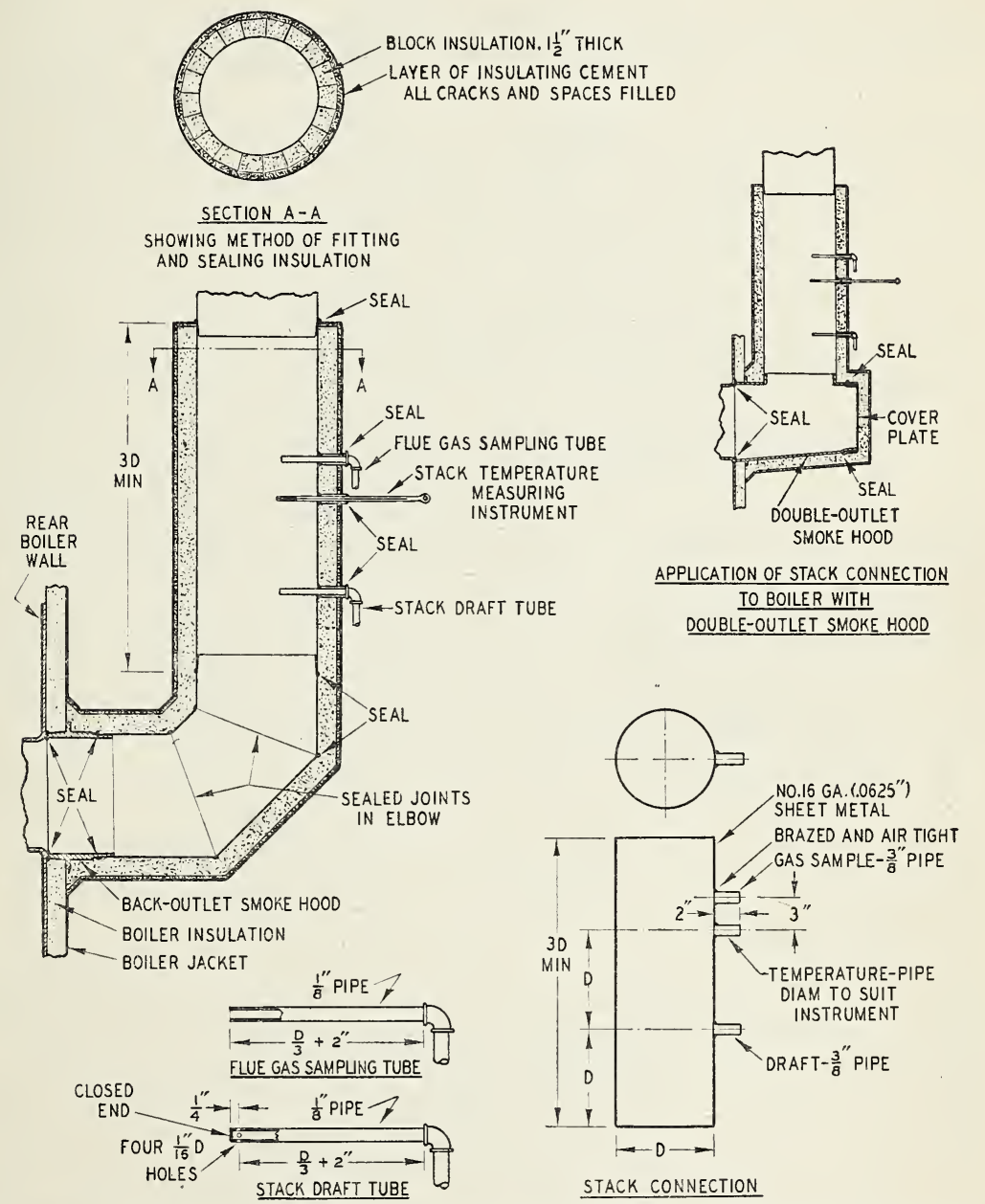

FIGURE 5. Stack connection for hand-fired boiler test (collar horizontally mounted).

Note 1.-Stack connection to be vertical.

Nоте 2.-Instruments must be installed from rear of stack connection.

Note 3.-Insulation on smoke hood, elbow, and stack connection to be $115 \mathrm{in}$. of mineral wool suitable for $1,200^{\circ} \mathrm{F}$, or bigher. Insulation must be thoroughly dry before tests are started. Any cracks which develop in the insulation must be sealed. 


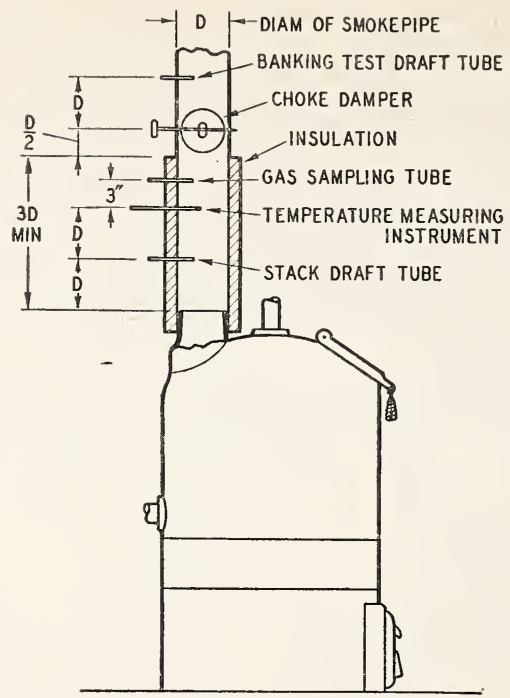

FIGURE 6. Stack connection for boilers with flue-outlet collar on the top.

\section{APPLICATION OF INSTRUMENTS ${ }^{1}$}

41. Stack pyrometry. - A thermometer or other suitable temperaturemeasuring device shall be used for measuring the temperature of the flue gases. This instrument shall be accurate within $5 \mathrm{deg} F$. Its temperature-sensitive end shall be from one-eighth to five-sixteenths inch in diameter, not longer than $1 \frac{11}{2}$ inches, and shall not be shielded. It shall be located as shown in figures 5 and 6 , with the tip pointing toward the front of the boiler and projecting into the stack connection one-third of the pipe diameter, but never less than 3 inches.

42. Flue gas sampling.-A flue-gas sampling tube may be installed as shown in figures 5 and 6 . If an open-end tube is used, it shall project into the stack connection one-third of the pipe diameter with the open end pointing toward the front of the boiler. If other methods of sampling are used, the sampling tube shall be placed so as to obtain an average sample.

43. Draft gages.-The stack draft gage shall be connected to a closed-end tube constructed and located as shown in figures 5 and 6 . The tube shall project horizontally one-third of the pipe diameter into the stack connection, pointing toward the front of the boiler. A similar tube may be used to measure the draft in the ashpit. This tube shall project 3 inches into the ashpit and be located approximately in the center of the ashpit side in which there is no draft door.

44. Water temperatures. - The water temperature shall be measured with temperature measuring devices accurate within $\pm 1 / 2$ deg $\mathrm{F}$, located as shown in figure 3, and as prescribed in paragraph 39.

45. Other observations. - The specifications covered in paragraphs 41 to 44 represent minimum requirements. It is left to the

1 All instruments in stack connection must be carefully sealed. 
discretion of the engineer to make additional observations and recordings, provided they do not affect the operation of the boiler or the accuracy of the tests.

\section{TEST PROCEDURE}

46. Number of tests. - At least two tests shall be conducted to determine the maximum output. One test also shall be conducted to determine banking characteristics on boilers with minimum horizontal combustion area below the firedoor sill of less than 125 square inches.

47. Cleaning of boiler.-The internal wet surfaces of the boiler shall be clean. The heating surface of the boiler shall be cleaned before each test.

48. Gaging kindling charge.-The weight of a suitable kindling charge shall be determined by estimate; this will commonly vary between 25 percent and 35 percent of the available fuel charge and, when leveled on the grates, will form a fuel bed from 3 inches to 6 inches thick. The estimated kindling' charge of black coal shall be weighed out and carefully leveled on the bare grates and the vertical distance from the surface of the fuel bed to the sill of the firedoor shall be measured with a gage similar to that shown in figures 7 and 8 . The fuel depth gage should be applied to all parts of the fuel bed to insure an accur ate measurement. The fuel bed may be tamped lightly with the gage to accelerate the leveling. The grates may be covered with paper to prevent the fuel falling through.
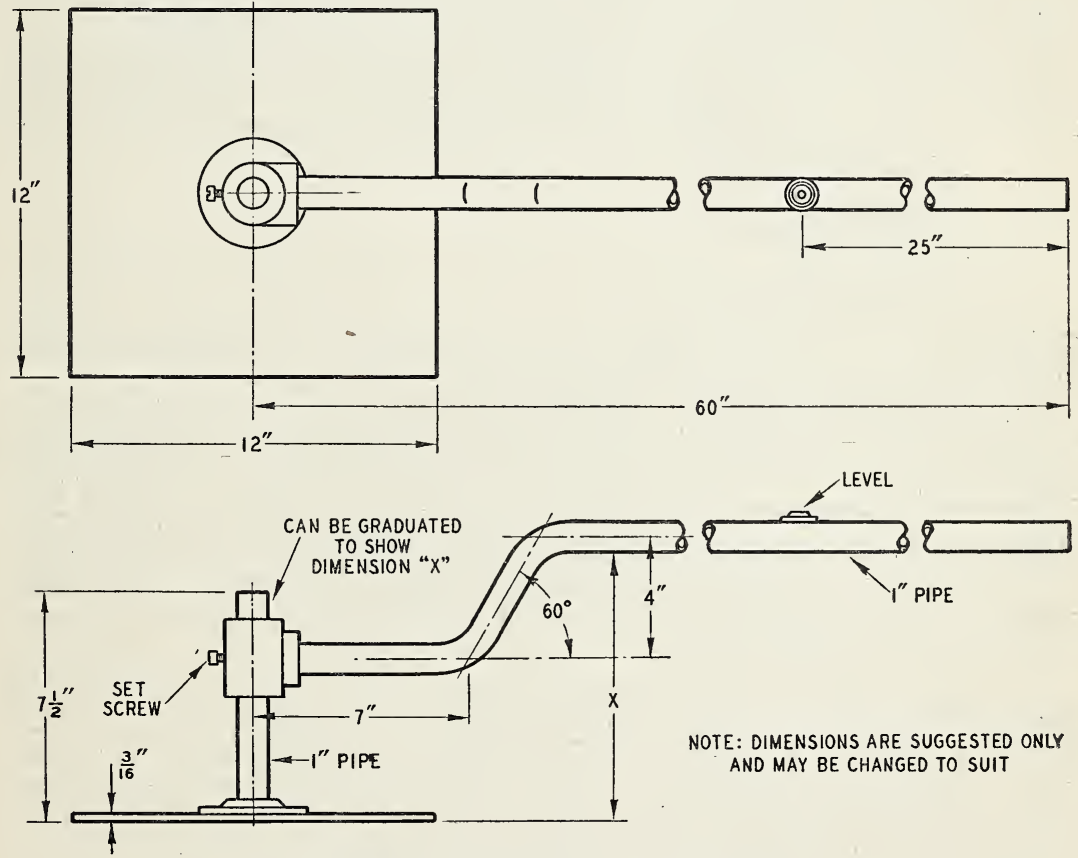

FIgURE 7. Suggested fuel-depth gage. 


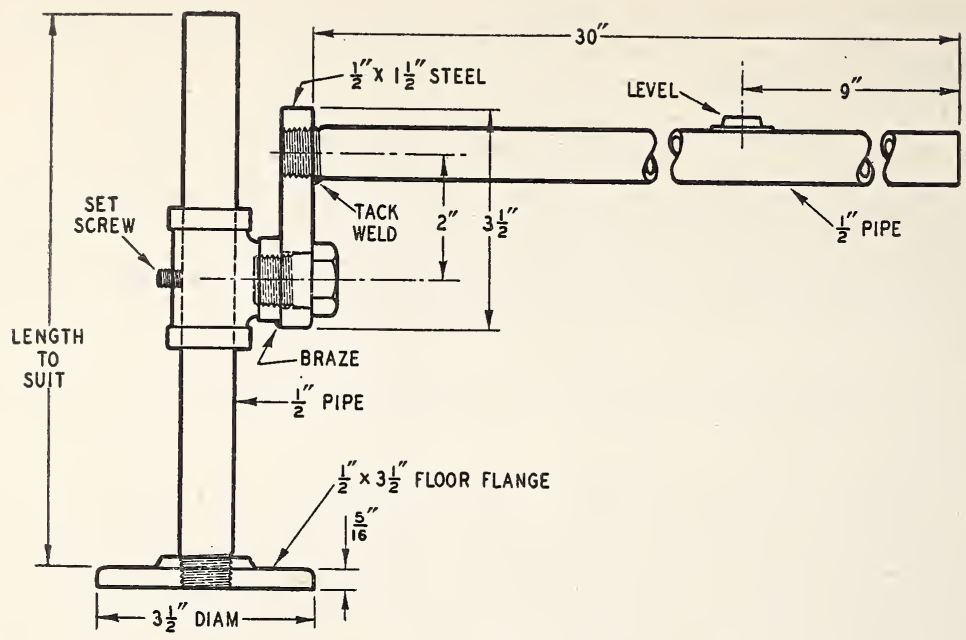

FigURE 8. Suggested fuel-depth gage for small boilers.

49. Variation in fuel charge.-When more than one fuel charge is fired, succeeding charges must not deviate by more than 10 percent from the available fuel charge and each must be fired at one time.

50. Secondary air. - If adjustable means are regularly provided for controlling secondary air, such means may be used to produce the most efficient combustion at any time during the test, but they shall not be sealed or altered from their commercial condition.

51. Attention to fire.- There shall be no attention to the fire except at the time of recharging the boiler or at the end of the test. Any one or a combination of the following constitutes attention to the fire:
(a) Charging fuel.
(b) Stoking.
(c) Cleaning fire.
(d) Leveling:
(e) Shaking grates.

Adjustment of the secondary air, as permitted by paragraph 50, is not considered attention to the fire.

52. Maximum output test.-Maximum output tests on boilers having. an output of 1,500,000 Btu per hour or less shall be conducted with ashpit door closed. The ashpit draft damper shall be set before the test is started and shall not be changed during the test. Maximum output tests on boilers having an output greater than 1,500,000 Btu per hour may be conducted with the ashpit door open. The stack draft shall be regulated in accordance with paragraph 53 for the stack height selected for the test.

53. Stack draft for maximum output test.-The stack draft shall be regulated according to the "Stack height-draft-temperature curves" (fig. 9) for the stack height specified for the test by the boiler manufacturer. (See, also, table 1.) Two minutes after completion of the firing, the stack temperature shall be read and the draft adjusted to conform to the proper curve. The draft shall be carefully regulated at intervals of 3 minutes or less until a stable stack temperature is 
reached. The intervals between adjustments may then be increased, but at no time shall the draft exceed that shown in the "Stack heightdraft-temperature curves" for the corresponding stack temperature.

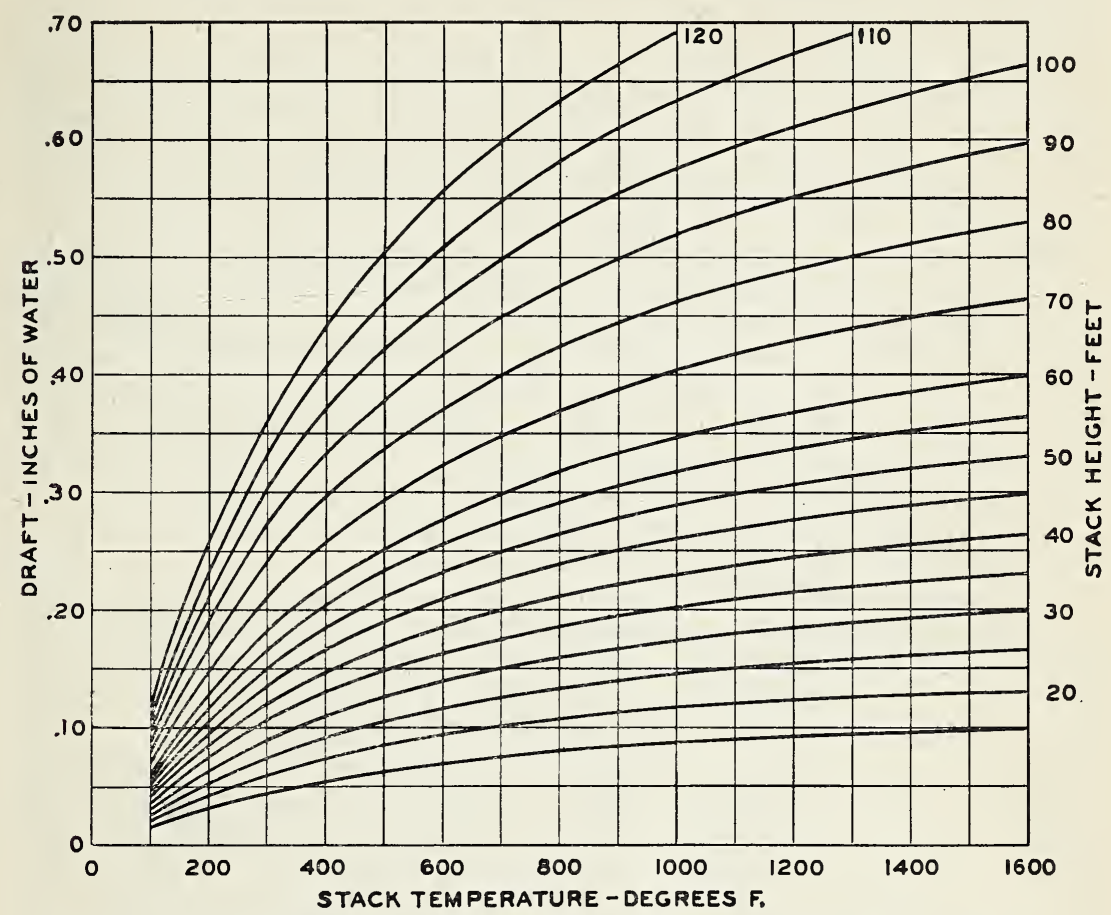

FIGURE 9. Stack height-draft-temperature curves.

54. Start of output test.-The black coal shall be removed and a preliminary fire built in the customary manner. The preliminary fire shall be continued until at least one full fuel charge has been burned. During at least the last hour of this preliminary run, the output rate should approximate that expected in the following test, and at the end of this preliminary period, the time, $\mathrm{CO}_{2}$, stack temperature, and draft shall be recorded as the first entry on the log sheet. The fire shall be thoroughly cleaned and the grates shaken until the top of the leveled incandescent fuel bed gages the same as that of the kindling: charge determined in accordance with paragraph 48 . The ashpit shall be thoroughly cleaned (immediately before firing) and after cleaning the ashpit door shall be closed, except as provided in paragraph 52. The firedoor shall be closed while the ashpit is being cleaned.

54a. An available fuel charge shall then be fired, a complete charge being fired at one time. The firing of the first shovelful of coal shall constitute the beginning of the test. At this time, recording of the water flow and inlet and outlet temperatures shall be started.

55. Measurement of output.-The rate of water flow through the boiler shall be constant within \pm 3 percent throughout the test. The 
water flowing from the outlet shall be collected in a suitable covered receptacle and weighed at least every 15 minutes. If the rate of water flow exceeds 2,000 pounds per hour, it is not necessary to collect all the water. Checks on the rates of water flow shall be made at intervals not to exceed 15 minutes. These checks shall be made by collecting the water for at least 1 minute in a suitable receptacle. Record exactly the length of time and weight of water. It is suggested that the rate of water flow in pounds per hour be determined approximately by dividing the estimated hourly output of the boiler in Btu/hr by 80 . If the preliminary cycle shows that this estimate is materially wrong, then the flow should be corrected before the final test is started.

55a. Water temperature rise and recording intervals.-The average temperature rise during the test shall be $80^{\circ} \pm 25^{\circ} \mathrm{F}$. Inlet temperature of the water shall be recorded at least every 15 minutes. The outlet temperature of the water shall be plotted on a curve, of which the abscissa is time. The readings of the outlet temperature shall be taken so frequently that normally the difference between two succeeding temperatures does not exceed $3 \mathrm{deg} F$. The readings need not be less than 3 minutes and shall not be more than 15 minutes apart.

56. Duration of output test.-Boilers may be tested using one or more available fuel charges in each output test.

57. End of output test. - The test shall be terminated when the condition of the fuel bed, as indicated by $\mathrm{CO}_{2}$, stack temperature, and draft, is approximately the same as the condition of the fuel bed at the end of the preliminary fire. The grates shall then be shaken and the fuel bed leveled and gaged. The ashpit shall be quickly cleaned and the cleanings placed in a tightly covered container for weighing. The fire shall then be quickly quenched, using only enough water to reduce the intense heat and leave the fuel bed dry. The end of the test shall be the time at which quenching is begun, and no output shall be recorded thereafter. The clinkers shall then be removed from the remaining fuel bed and weighed together with any clinkers removed from the firebox at the end of previous firing periods if more than one fuel charge has been fired. The residue remaining on the grates shall then be placed in a tightly covered container and weighed.

57a. The weight of the dry residue remaining on the grates at the end of the test shall not vary by more than 25 percent from the weight of the incandescent kindling fuel bed (weight of black kindling fuel charge $\times 0.87$ ).

58. Banking test draft adjustments.-The banking test shall be conducted with the ashpit draft damper and choke damper in the stack connection closed. The draft measured beyond the choke damper in the stack connection (fig. 6) at no time shall be less than 0.01 inch.

59. Start of banking test.-Prepare a kindling charge similar to that described in paragraph 48. After the kindling charge is well ignited, fire a charge approximating the weight of an available fuel charge. Continue at a rate of approximately one-half the maximum output rate for at least 2 hours. Bank fire by making the adjustments described in paragraph 58. Adjustable means for regulating secondary air may be used for checking the fire.

60. Duration of banking test.-Continue the banking test for at least 12 hours after banking. During the last 2 hours of the banking 
test, record at 15-minute intervals the inlet and outlet temperatures and flow of water.

61. Pick-up at end of banking test.-Record the stack temperature, open those dampers that were closed at the start, but do not shake grates. Record the stack temperature every 5 minutes and regulate the draft as described in paragraph 53. The test shall be terminated 30 minutes after opening the dampers, at which time the stack temperature shall have risen at least $100^{\circ} \mathrm{F}$.

\section{CALCULATIONS, DATA, AND REPORT SHEETS}

62. Recording of test data.-Forms for recording test data are shown on pages 16 and 17 . The data shall be recorded at intervals not exceeding 15 minutes, unless otherwise specified.

63. Calculation of output.

63a. Maximum output is calculated as follows:

(1) Total output in Btu=

$$
\mathrm{W}(\mathrm{OT}-\mathrm{IT})+\mathrm{C}\left[\frac{(\mathrm{EOT}+\mathrm{EIT})}{2}-\frac{(\mathrm{SOT}+\mathrm{SIT})}{2}\right]
$$

where

$\mathrm{W}=\mathrm{W}$ eight of water flowing through boiler during test, $\mathrm{lb}$ $\mathrm{OT}=$ Average outlet temperature of water, ${ }^{\circ} \mathrm{F}$

$\mathrm{IT}=$ Average inlet temperature of water, ${ }^{\circ} \mathrm{F}$

$\mathrm{C}=$ Water content of boiler, $\mathrm{lb}$

$\mathrm{EOT}=$ Outlet temperature at end of test, ${ }^{\circ} \mathrm{F}$

$\mathrm{EIT}=$ Inlet temperature at end of test, ${ }^{\circ} \mathrm{F}$

$\mathrm{SOT}=$ Outlet temperature at start of test, ${ }^{\circ} \mathrm{F}$

$\mathrm{SIT}=$ Inlet temperature at start of test, ${ }^{\circ} \mathrm{F}$.

Note. - The average outlet temperature is the average of the curve (mean ordinate) of water-outlet temperatures between start and end of test.

(2) Output rate, $\mathrm{Btu} / \mathrm{hr}=$

Total output, Btu

Duration of test, $\mathrm{hr}$.

(3) Net dry fuel used=

$\frac{\text { Item } 9^{2} \times 0.87+\text { item } 11^{2}\left(1-\frac{\% \text { moisture }}{100}\right)-\text { item } 13^{2}}{1-\frac{\% \text { ash }}{100}} \times 1.05$.

(4) Time available fuel will last, $\mathrm{hr}=$

$$
\frac{\text { Duration of test } \times 13,000 \times \text { available fuel }}{\text { Dry heat value of test fuel } \times \text { net dry fuel used }} \text {. }
$$


(5) Maximum output in $\mathrm{Btu} / \mathrm{hr}=$

$\frac{\text { Output rate } \times \text { time available fuel will last. }}{6}$.

(6) If the time available fuel will last is more than 6 hours, maximum output in $\mathrm{Btu} / \mathrm{hr}=$ output rate in $\mathrm{Btu} / \mathrm{hr}$.

63b. Output rate during last 2 hours of banking test is calculated as follows:

$$
\text { Output }=\frac{(\mathrm{OT}-\mathrm{IT}) \mathrm{W}}{2},
$$

where

$\mathrm{OT}=$ Average outlet temperature of water, last $2 \mathrm{hr},{ }^{\circ} \mathrm{F}$

$\mathrm{IT}=$ Average inlet temperature of water, last $2 \mathrm{hr},{ }^{\circ} \mathrm{F}$

$\mathrm{W}=\mathrm{Weight}$ of water flowing through boiler, last $2 \mathrm{hr}, \mathrm{lb}$.

\section{HAND-FIRED HOT-WATER-SUPPLY BOILER TEST- LOG SHEET}

Conducted by

Date

Test No

Boiler section assemblage

Remarks

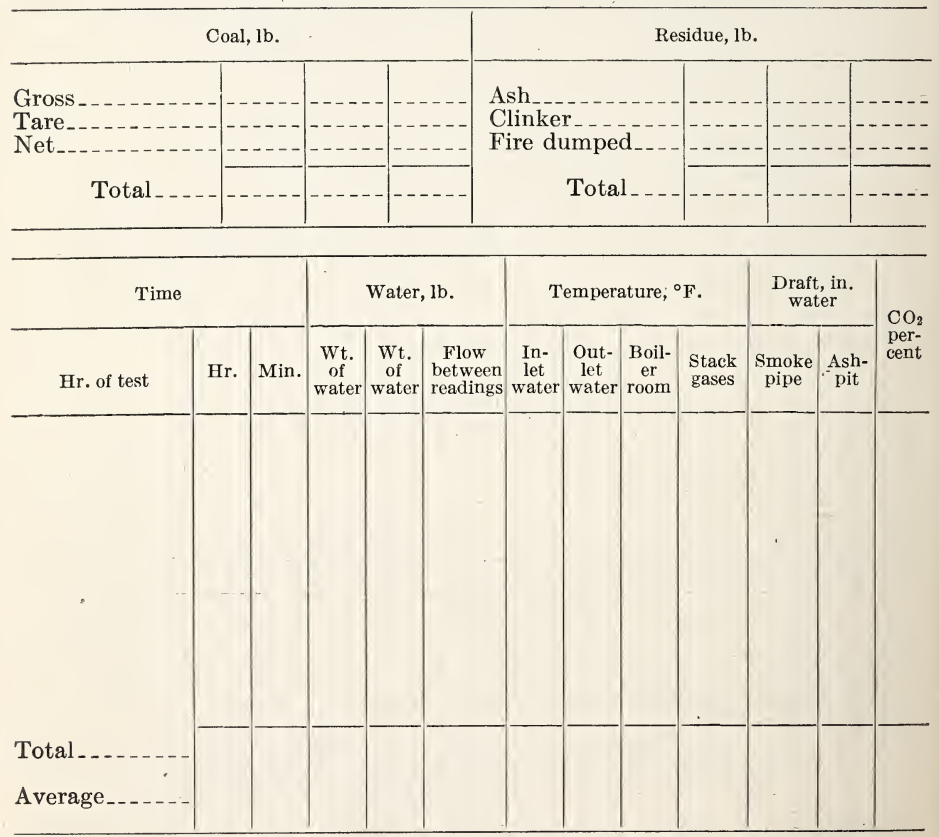

Manufacturer

Boiler 


\section{HAND-FIRED HOT-WATER-SUPPLY BOILER TEST- REPORT SHEET}

\section{Eoiler}

Name, number

Company name

Grate area

Fuel capacity _._._. lb, Fuel available

Outlets used: Size ...... in., Number

$\mathrm{ft}^{2}$, Water content lb.

Fuel

Kind.

Ash fusion temp

Size

${ }^{\circ}$ Calorific value (dry basis)

Proximate analysis

Ultimate analysis*

Volatile matter

Fixed carbon

Ash

Sulfur*-

Moisture

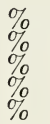

Carbon*

Hydrogen*

Nitrogen*

Oxygen*

Sulfur*

General:

1. Test number

2. Type of test (banking or output)

4. Stack height for which draft was regulated .................

5. Room temperature

6. Duration of test _........... $\mathrm{hr}$ Input

7. Thickness of rekindling fuel bed_._- in.

8. Thickness of fuel bed at end....... in.

9. Weight of black fuel corresponding to item 7 ... lb

10. Number of fuel charges

11. Total fuel charge

12. Average fuel charge _........ lb

13. Total residue at end of test.......

14. Net dry fuel used .

15. Time available fuel will last_........ $\mathrm{hr}$

Location

lib.

Ultimate analysis*

Products of combustion

16. Carbon dioxide $\left(\mathrm{CO}_{2}\right)$

17. Oxygen $\left(\mathrm{O}_{2}\right)^{*}$

18. Carbon monoxide $(\mathrm{CO})^{*}$

Draft

20. Smoke pipe________._. in. water

21. Ashpit _... in. water

22. Inlet water temperature.

(-.-

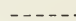

- no
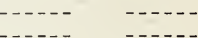

$-\cdots--$
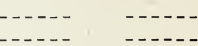

23. Outlet water temperature

- - - -
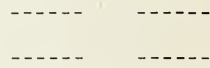

24. Water collected................ lb

25. Change in boiler water heat...... Btu

26. Total output._.

27. Output rate_._.

28. Maximum output ....... Btu/hr

29. Capacity _. _._. gal heated $100^{\circ} \mathrm{F} / 3 \mathrm{hr}$

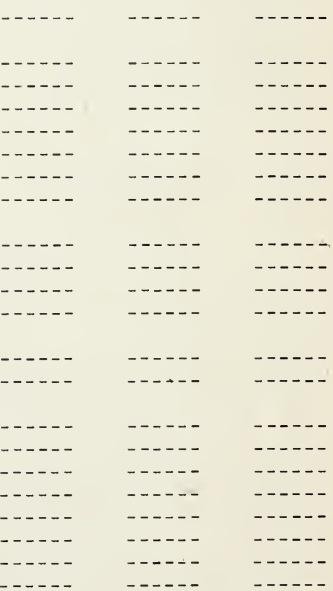

Laboratory name

Date submitted

Location

By

*Determination of these items is not mandatory. 


\section{TABLE 1. Stack height-Draft temperature table}

[Figures in body of table are values of draft in inches of water]

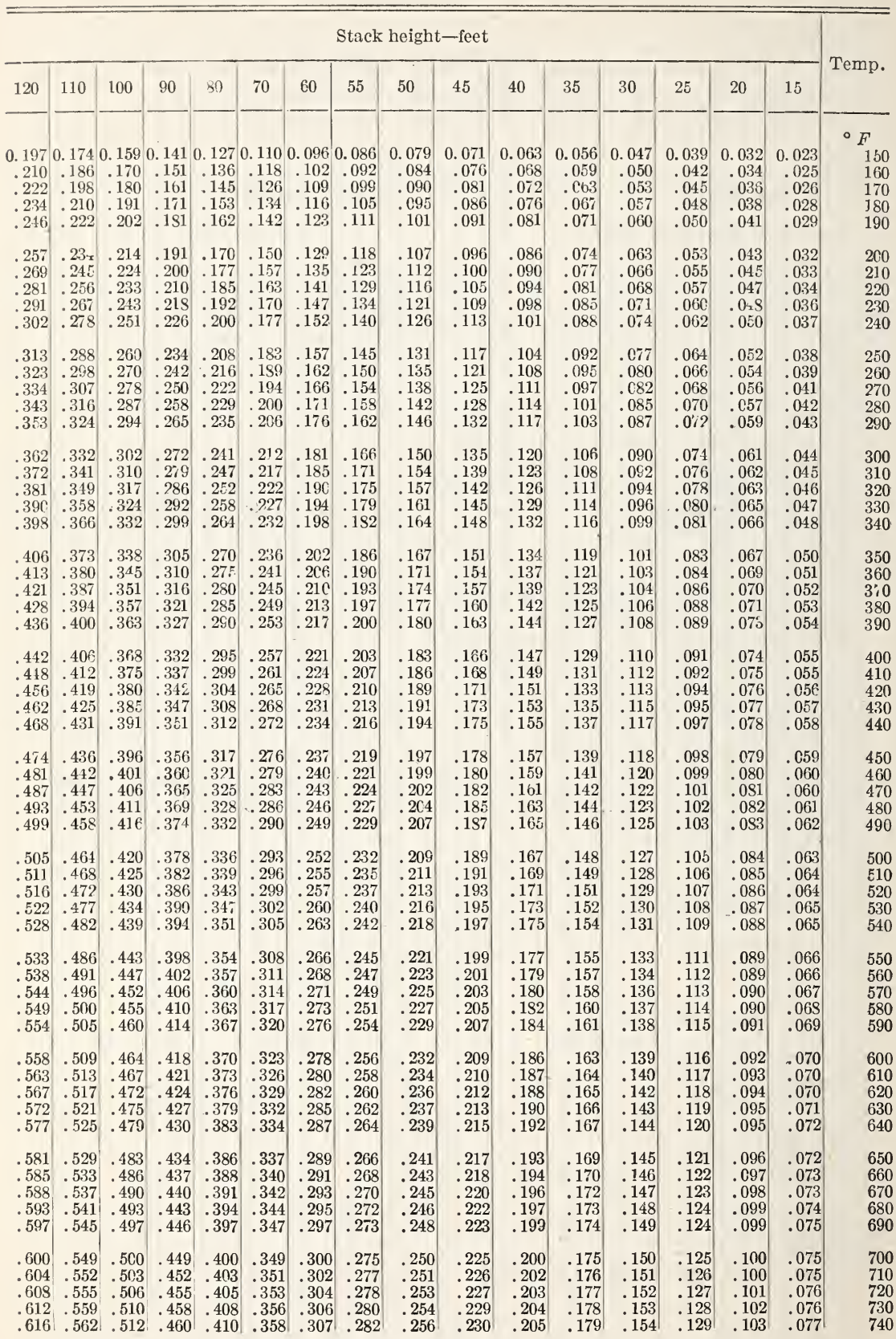


TABLE 1. Stack height-Draft temperature table-Continued

\begin{tabular}{|c|c|c|c|c|c|c|c|c|c|c|c|c|c|c|c|c|}
\hline \multicolumn{16}{|c|}{ Stack height-fect } & \multirow{2}{*}{ Temp. } \\
\hline 120 & 110 & 100 & 90 & 80 & 70 & 60 & 55 & 50 & 45 & 40 & 35 & 30 & 25 & 20 & 15 & \\
\hline $\begin{array}{l}.623 \\
.627 \\
.630 \\
.633\end{array}$ & $\begin{array}{r}0.566 \\
.569 \\
.572 \\
.576 \\
.579\end{array}$ & $\begin{array}{r}0.516 \\
.518 \\
.521 \\
.524 \\
.527\end{array}$ & $\begin{array}{r}0.463 \\
.465 \\
.468 \\
.470 \\
.473\end{array}$ & $\begin{array}{r}0.413 \\
.415 \\
.417 \\
.420 \\
.422\end{array}$ & $\begin{array}{r}0.360 \\
.362 \\
.364 \\
.366 \\
.368\end{array}$ & $\begin{array}{r}0.309 \\
.311 \\
.313 \\
.314 \\
.316\end{array}$ & $\begin{array}{r}0283 \\
.285 \\
.287 \\
.289 \\
.290\end{array}$ & $\begin{array}{r}0.257 \\
.259 \\
.261 \\
.262 \\
.263\end{array}$ & $\begin{array}{r}0.232 \\
.233 \\
.234 \\
.236 \\
.237\end{array}$ & $\begin{array}{r}0.206 \\
.207 \\
.209 \\
.210 \\
.211\end{array}$ & $\begin{array}{r}0.180 \\
.181 \\
.182 \\
.183 \\
.184\end{array}$ & $\begin{array}{r}0.155 \\
.156 \\
.157 \\
.158 \\
.159\end{array}$ & $\begin{array}{r}0.129 \\
.130 \\
.131 \\
.132 \\
.133\end{array}$ & $\begin{array}{r}0.103 \\
.104 \\
.165 \\
.105 \\
.105\end{array}$ & $\begin{array}{r}0.077 \\
.078 \\
.078 \\
.079 \\
.079\end{array}$ & $\begin{array}{c}\circ{ }^{\circ} F \\
750 \\
760 \\
770 \\
780 \\
790\end{array}$ \\
\hline $\begin{array}{l}.637 \\
.640 \\
.643 \\
.647 \\
.649\end{array}$ & $\begin{array}{l}.582 \\
.585 \\
.588 \\
.591 \\
.594\end{array}$ & $\begin{array}{l}.530 \\
.532 \\
.535 \\
.538 \\
.541\end{array}$ & $\begin{array}{l}.476 \\
.478 \\
.480 \\
.483 \\
.486\end{array}$ & $\begin{array}{r}.424 \\
.427 \\
.429 \\
.431 \\
.433\end{array}$ & $\begin{array}{l}.371 \\
.373 \\
.374 \\
.376 \\
.378\end{array}$ & $\begin{array}{l}.318 \\
.320 \\
.321 \\
.323 \\
.324\end{array}$ & $\begin{array}{l}.292 \\
.293 \\
.295 \\
.296 \\
.298\end{array}$ & $\begin{array}{l}.265 \\
.266 \\
.267 \\
.269 \\
.270\end{array}$ & $\begin{array}{l}.238 \\
.240 \\
.241 \\
.242 \\
.243\end{array}$ & $\begin{array}{l}.212 \\
.213 \\
.215 \\
.216 \\
.217\end{array}$ & $\begin{array}{l}.185 \\
.186 \\
.187 \\
.188 \\
.189\end{array}$ & $\begin{array}{l}.159 \\
.160 \\
.161 \\
.162 \\
.163\end{array}$ & $\begin{array}{r}.133 \\
.134 \\
.135 \\
.135 \\
.136\end{array}$ & $\begin{array}{l}.106 \\
.106 \\
.107 \\
.108 \\
.108\end{array}$ & $\begin{array}{l}.080 \\
.080 \\
.080 \\
.081 \\
.081\end{array}$ & $\begin{array}{l}800 \\
810 \\
820 \\
830 \\
840\end{array}$ \\
\hline $\begin{array}{l}.652 \\
.656 \\
.658 \\
.661 \\
.664\end{array}$ & $\begin{array}{l}.597 \\
.600 \\
.603 \\
.606 \\
.609\end{array}$ & $\begin{array}{l}.543 \\
.545 \\
.548 \\
.550 \\
.553\end{array}$ & $\begin{array}{l}.488 \\
.491 \\
.493 \\
.495 \\
.497\end{array}$ & $\begin{array}{l}.435 \\
.437 \\
.439 \\
.441 \\
.443\end{array}$ & $\begin{array}{l}.380 \\
.382 \\
.384 \\
.386 \\
.388\end{array}$ & $\begin{array}{l}.326 \\
.327 \\
.329 \\
.330 \\
.332\end{array}$ & $\begin{array}{l}.299 \\
.301 \\
.302 \\
.303 \\
.305\end{array}$ & $\begin{array}{l}.272 \\
.273 \\
.274 \\
.276 \\
.277\end{array}$ & $\begin{array}{l}.245 \\
.246 \\
.247 \\
.248 \\
.249\end{array}$ & $\begin{array}{l}.218 \\
.219 \\
.220 \\
.221 \\
.222\end{array}$ & $\begin{array}{l}.190 \\
.191 \\
.192 \\
.193 \\
.194\end{array}$ & $\begin{array}{l}.161 \\
.164 \\
.165 \\
.165 \\
.166\end{array}$ & $\begin{array}{l}.137 \\
.137 \\
.138 \\
.138 \\
.139\end{array}$ & $\begin{array}{r}.109 \\
.110 \\
.110 \\
.110 \\
.111\end{array}$ & $\begin{array}{l}.081 \\
.082 \\
.082 \\
.083 \\
.083\end{array}$ & $\begin{array}{l}850 \\
860 \\
870 \\
880 \\
890\end{array}$ \\
\hline $\begin{array}{l}.667 \\
.670 \\
.672 \\
.675 \\
.677\end{array}$ & $\begin{array}{l}.612 \\
.614 \\
.616 \\
.618 \\
.621\end{array}$ & $\begin{array}{l}.555 \\
.557 \\
.560 \\
.562 \\
.564\end{array}$ & $\begin{array}{r}.500 \\
502 \\
.504 \\
.506 \\
.508\end{array}$ & $\begin{array}{l}.445 \\
.446 \\
.448 \\
.450 \\
.452\end{array}$ & $\begin{array}{l}.390 \\
.391 \\
.392 \\
.394 \\
.296\end{array}$ & $\begin{array}{l}.334 \\
.335 \\
.336 \\
.337 \\
.338\end{array}$ & $\begin{array}{l}.306 \\
.307 \\
.309 \\
.310 \\
.312\end{array}$ & $\begin{array}{l}.278 \\
.279 \\
.280 \\
.282 \\
.283\end{array}$ & $\begin{array}{l}.250 \\
.251 \\
.252 \\
.253 \\
.254\end{array}$ & $\begin{array}{l}.223 \\
.224 \\
.225 \\
.226 \\
.227\end{array}$ & $\begin{array}{r}.195 \\
.196 \\
.197 \\
.198\end{array}$ & $\begin{array}{l}.167 \\
.168 \\
.168 \\
.169 \\
.170\end{array}$ & $\begin{array}{l}.139 \\
.140 \\
.141 \\
.142 \\
.142\end{array}$ & $\begin{array}{l}.112 \\
.112 \\
.112 \\
.113 \\
.114\end{array}$ & $\begin{array}{l}.084 \\
.084 \\
.084 \\
.085 \\
.085\end{array}$ & $\begin{array}{l}900 \\
910 \\
920 \\
930 \\
940\end{array}$ \\
\hline $\begin{array}{l}.680 \\
.683 \\
.686 \\
.688 \\
.691\end{array}$ & $\begin{array}{l}.624 \\
.626 \\
.629 \\
.631 \\
.633\end{array}$ & $\begin{array}{l}.566 \\
.568 \\
.570 \\
.572 \\
.574\end{array}$ & $\begin{array}{l}.510 \\
.512 \\
.514 \\
.516 \\
.518\end{array}$ & $\begin{array}{l}.453 \\
.455 \\
.457 \\
.459 \\
.460\end{array}$ & $\begin{array}{l}.397 \\
.399 \\
.400 \\
.402 \\
.403\end{array}$ & $\begin{array}{l}.340 \\
.341 \\
.343 \\
.344 \\
.345\end{array}$ & $\begin{array}{l}.313 \\
.314 \\
.315 \\
.316 \\
.317\end{array}$ & $\begin{array}{l}.28 \\
.28 \\
.28 \\
.28 \\
.28\end{array}$ & $\begin{array}{l}.25 \\
.25 \\
.25 \\
.25 \\
.25\end{array}$ & $\begin{array}{l}.227 \\
.228 \\
.229 \\
.230 \\
.231\end{array}$ & .201 & & $\begin{array}{l}.143 \\
.144 \\
.144 \\
.145 \\
.145\end{array}$ & $\begin{array}{r}.115 \\
.115 \\
.116\end{array}$ & $\begin{array}{r}.085 \\
.085 \\
.086 \\
.086 \\
.086\end{array}$ & $\begin{array}{l}950 \\
960 \\
970 \\
980 \\
990\end{array}$ \\
\hline $\begin{array}{l}.693 \\
.696 \\
.698 \\
.701 \\
.703\end{array}$ & $\begin{array}{l}.635 \\
.637 \\
.640 \\
.642 \\
.644\end{array}$ & $\begin{array}{l}.577 \\
.578 \\
.581 \\
.583 \\
.585\end{array}$ & $\begin{array}{l}.520 \\
.521 \\
.523 \\
.524 \\
.526\end{array}$ & $\begin{array}{l}.461 \\
.463 \\
.465 \\
.467 \\
.468\end{array}$ & $\begin{array}{l}.405 \\
.406 \\
.408 \\
.409 \\
.411\end{array}$ & $\begin{array}{l}.347 \\
.348 \\
.349 \\
.350 \\
.351\end{array}$ & $\begin{array}{l}.318 \\
.319 \\
.320 \\
.321 \\
.322\end{array}$ & $\begin{array}{l}.289 \\
.290 \\
.291 \\
.292 \\
.293\end{array}$ & $\begin{array}{l}.260 \\
.261 \\
.262 \\
.263 \\
.264\end{array}$ & $\begin{array}{l}.231 \\
.233 \\
.234 \\
.235 \\
.235\end{array}$ & .202 & & $\begin{array}{l}.146 \\
.146 \\
.147 \\
.147 \\
.148\end{array}$ & $\begin{array}{l}.116 \\
.116 \\
.117 \\
.117 \\
.118\end{array}$ & $\begin{array}{l}.086 \\
.087 \\
.087\end{array}$ & $\begin{array}{l}.000 \\
010 \\
020 \\
030 \\
040\end{array}$ \\
\hline $\begin{array}{l}.706 \\
.708 \\
.710 \\
.712 \\
.715\end{array}$ & $\begin{array}{l}.647 \\
.649 \\
.651 \\
.653 \\
.655\end{array}$ & $\begin{array}{l}.587 \\
.589 \\
.591 \\
.592 \\
.594\end{array}$ & $\begin{array}{l}.528 \\
.530 \\
.532 \\
.533 \\
.535\end{array}$ & $\begin{array}{l}.470 \\
.471 \\
.473 \\
.474 \\
.475\end{array}$ & $\begin{array}{l}.412 \\
.413 \\
.415 \\
.416 \\
.417\end{array}$ & $\begin{array}{l}.352 \\
.353 \\
.355 \\
.356 \\
.357\end{array}$ & $\begin{array}{l}.323 \\
.325 \\
.326 \\
.327 \\
.328\end{array}$ & $\begin{array}{l}.29 \\
.29 \\
.29 \\
.29 \\
.29\end{array}$ & $\begin{array}{l}.265 \\
.26 \\
.266 \\
.26 \\
.268\end{array}$ & $\begin{array}{l}.236 \\
.237 \\
.238 \\
.239 \\
.239\end{array}$ & .20 & & $\begin{array}{l}.149 \\
.149 \\
.150 \\
.150\end{array}$ & & $\begin{array}{l}.089 \\
.089 \\
.090 \\
.090\end{array}$ & $\begin{array}{l}, 060 \\
1,070 \\
1,080 \\
1,090\end{array}$ \\
\hline $\begin{array}{l}.717 \\
.719 \\
.721 \\
.723 \\
.726\end{array}$ & $\begin{array}{l}.657 \\
.659 \\
.661 \\
.662 \\
.664\end{array}$ & $\begin{array}{l}.597 \\
.598 \\
.600 \\
.601 \\
.603\end{array}$ & $\begin{array}{l}.538 \\
.539 \\
.540 \\
.541 \\
.543\end{array}$ & $\begin{array}{l}.477 \\
.479 \\
.480 \\
.481 \\
.483\end{array}$ & $\begin{array}{l}.418 \\
.420 \\
.421 \\
.422 \\
.424\end{array}$ & $\begin{array}{l}.359 \\
.359 \\
.360 \\
.361 \\
.362\end{array}$ & $\begin{array}{l}.328 \\
.329 \\
.331 \\
.332 \\
.333\end{array}$ & $\begin{array}{l}.299 \\
.299 \\
.300 \\
.301 \\
.302\end{array}$ & $\begin{array}{l}.268 \\
.269 \\
.270 \\
.271 \\
.272\end{array}$ & $\begin{array}{l}.239 \\
.240 \\
.241 \\
.242 \\
.243\end{array}$ & $\begin{array}{r}.211 \\
.212\end{array}$ & .180 & $\begin{array}{l}.152 \\
.152\end{array}$ & $\begin{array}{r}.122 \\
.122\end{array}$ & $\begin{array}{l}.091 \\
.091 \\
.091\end{array}$ & $\begin{array}{l}1,120 \\
1,130 \\
1,140\end{array}$ \\
\hline $\begin{array}{l}.728 \\
.730 \\
.732 \\
.734 \\
.736\end{array}$ & $\begin{array}{l}.666 \\
.668 \\
.670 \\
.672 \\
.674\end{array}$ & $\begin{array}{l}.605 \\
.606 \\
.608 \\
.610 \\
.612\end{array}$ & $\begin{array}{l}.545 \\
.546 \\
.547 \\
.549 \\
.550\end{array}$ & $\begin{array}{l}.484 \\
.485 \\
.486 \\
.488 \\
.489\end{array}$ & $\begin{array}{l}.425 \\
.426 \\
.427 \\
.428 \\
.429\end{array}$ & $\begin{array}{l}.363 \\
.364 \\
.365 \\
.366 \\
.367\end{array}$ & $\begin{array}{l}.334 \\
.334 \\
.335 \\
.336 \\
.337\end{array}$ & .30 & $\begin{array}{r}.27 \\
.27 \\
.27\end{array}$ & .24 & .21 & & .154 & $\begin{array}{l}.123 \\
.123 \\
.124\end{array}$ & . 092 & $\begin{array}{l}1,180 \\
1,190\end{array}$ \\
\hline $\begin{array}{l}.738 \\
.740 \\
.742 \\
.744 \\
.746\end{array}$ & $\begin{array}{l}.675 \\
.677 \\
.679 \\
.681 \\
.682\end{array}$ & $\begin{array}{l}.614 \\
.615 \\
.616 \\
.617 \\
.619\end{array}$ & $\begin{array}{l}.551 \\
.553 \\
.554 \\
.556 \\
.557\end{array}$ & $\begin{array}{l}.491 \\
.492 \\
.493 \\
.494 \\
.495\end{array}$ & $\begin{array}{l}.430 \\
.431 \\
.432 \\
.433 \\
.435\end{array}$ & $\begin{array}{l}.368 \\
.369 \\
.370 \\
.371 \\
.372\end{array}$ & $\begin{array}{l}.338 \\
.339 \\
.340 \\
.341 \\
.342\end{array}$ & .310 & .279 & $\begin{array}{r}.248 \\
.248 \\
.249\end{array}$ & $\begin{array}{l}.216 \\
.217\end{array}$ & .186 & $\begin{array}{l}.156 \\
.156\end{array}$ & $\begin{array}{l}.125 \\
.125\end{array}$ & & $\begin{array}{l}1,210 \\
1,220 \\
1,230 \\
1,240\end{array}$ \\
\hline $\begin{array}{l}.747 \\
.749 \\
.751 \\
.753 \\
.754\end{array}$ & $\begin{array}{l}.684 \\
.686 \\
.687 \\
.689 \\
.690\end{array}$ & $\begin{array}{l}.621 \\
.622 \\
.624 \\
.625 \\
.627\end{array}$ & $\begin{array}{l}.558 \\
.560 \\
.561 \\
.562 \\
.564\end{array}$ & $\begin{array}{r}.496 \\
.497 \\
.498 \\
.500 \\
.501\end{array}$ & $\begin{array}{l}.436 \\
.437 \\
.438 \\
.439 \\
.440\end{array}$ & $\begin{array}{l}.373 \\
.374 \\
.375 \\
.375 \\
.376\end{array}$ & $\begin{array}{l}.343 \\
.344 \\
.344 \\
.345 \\
.346\end{array}$ & .314 & .28 & .252 & .21 & .18 & .158 & .126 & & $\begin{array}{l}1,270 \\
1,280 \\
1,290\end{array}$ \\
\hline $\begin{array}{l}.756 \\
.758 \\
.759 \\
.761 \\
.763\end{array}$ & $\begin{array}{l}.693 \\
.694 \\
.696 \\
.697 \\
.699\end{array}$ & $\begin{array}{l}.629 \\
.630 \\
.631 \\
.632 \\
.633\end{array}$ & $\begin{array}{l}.565 \\
.566 \\
.567 \\
.568 \\
.570\end{array}$ & $\begin{array}{l}.503 \\
.504 \\
.504 \\
.505 \\
.506\end{array}$ & $\begin{array}{l}.441 \\
.441 \\
.442 \\
.443 \\
.444\end{array}$ & $\begin{array}{l}.377 \\
.378 \\
.379 \\
.380 \\
.381\end{array}$ & $\begin{array}{l}.346 \\
.347 \\
.348 \\
.349 \\
.350\end{array}$ & $\begin{array}{l}.317 \\
.318\end{array}$ & $\begin{array}{l}.285 \\
.286\end{array}$ & $\begin{array}{l}.254 \\
.255\end{array}$ & $\begin{array}{l}.220 \\
.220 \\
.221 \\
.221 \\
.222\end{array}$ & .191 & $\begin{array}{l}.160 \\
.160\end{array}$ & $\begin{array}{l}.127 \\
.128\end{array}$ & & $\begin{array}{l}1,310 \\
1,320 \\
1,330 \\
1,340\end{array}$ \\
\hline $\begin{array}{l}.764 \\
.766 \\
.767 \\
.768 \\
770\end{array}$ & $\begin{array}{l}.700 \\
.701 \\
.703 \\
.704 \\
.705\end{array}$ & $\begin{array}{l}.635 \\
.636 \\
.638 \\
.639\end{array}$ & $\begin{array}{l}.571 \\
.572 \\
.573 \\
.574 \\
.576\end{array}$ & $\begin{array}{l}.508 \\
.510 \\
.511 \\
.512\end{array}$ & $\begin{array}{l}.445 \\
.446 \\
.447 \\
.448 \\
.449\end{array}$ & $\begin{array}{l}.382 \\
.383 \\
.383 \\
.384 \\
.385\end{array}$ & $\begin{array}{l}.3 \\
.3 \\
.3 \\
.3 \\
.3\end{array}$ & 3 & 28 & .2 & $\begin{array}{l}.22 \\
.22 \\
.22 \\
.22 \\
.22\end{array}$ & .193 & $\begin{array}{l}.16 \\
.16 \\
.16\end{array}$ & $\begin{array}{l}.128 \\
.128 \\
.129\end{array}$ & $\begin{array}{l}.096 \\
.096 \\
.096\end{array}$ & $\begin{array}{l}1,370 \\
1,380 \\
1,390\end{array}$ \\
\hline
\end{tabular}


TABLe 1. Stack height-Draft temperature table-Continued

\begin{tabular}{|c|c|c|c|c|c|c|c|c|c|c|c|c|c|c|c|c|}
\hline \multicolumn{16}{|c|}{ Stack height-feet } & \multirow{2}{*}{ Temp. } \\
\hline 120 & 110 & 100 & 90 & 80 & 70 & 60 & 55 & 50 & 45 & 40 & 35 & 30 & 25 & 20 & 15 & \\
\hline $\begin{array}{l}772 \\
.773 \\
.774 \\
.776 \\
.777\end{array}$ & $\begin{array}{r}0.706 \\
.708 \\
.709 \\
.711 \\
.713\end{array}$ & $\begin{array}{r}0.641 \\
.643 \\
.644 \\
.645 \\
.647\end{array}$ & $\begin{array}{r}0.577 \\
.578 \\
.579 \\
.581 \\
.582\end{array}$ & $\begin{array}{r}0.512 \\
.513 \\
.514 \\
.515 \\
.517\end{array}$ & $\begin{array}{r}0.450 \\
.451 \\
.451 \\
.452 \\
.453\end{array}$ & $\begin{array}{r}0.385 \\
.386 \\
.387 \\
.388 \\
.389\end{array}$ & $\begin{array}{r}0.353 \\
.354 \\
.355 \\
.356 \\
.356\end{array}$ & $\begin{array}{r}0.321 \\
.322 \\
.323 \\
.324 \\
.324\end{array}$ & $\begin{array}{r}0.289 \\
.289 \\
.290 \\
.290 \\
.291\end{array}$ & $\begin{array}{r}0.256 \\
.257 \\
.258 \\
.258 \\
.259\end{array}$ & $\begin{array}{r}0.224 \\
.225 \\
.225 \\
.226 \\
.226\end{array}$ & $\begin{array}{r}0.193 \\
.193 \\
.193 \\
.194 \\
.194\end{array}$ & $\begin{array}{r}0.162 \\
.162 \\
.162 \\
.163 \\
.163\end{array}$ & $\begin{array}{r}0.129 \\
.129 \\
.130 \\
.130 \\
.130\end{array}$ & $\begin{array}{r}0.096 \\
.097 \\
.097 \\
.097 \\
.097\end{array}$ & $\begin{array}{l}{ }^{\circ} F \\
1,400 \\
1,410 \\
1,420 \\
1,430 \\
1,440\end{array}$ \\
\hline $\begin{array}{r}.779 \\
.780 \\
.782 \\
.783 \\
.784\end{array}$ & $\begin{array}{l}.714 \\
.715 \\
.717 \\
.718 \\
.719\end{array}$ & $\begin{array}{r}.648 \\
.649 \\
.651 \\
.652 \\
.653\end{array}$ & $\begin{array}{l}.583 \\
.584 \\
.585 \\
.586 \\
.587\end{array}$ & $\begin{array}{l}.518 \\
.519 \\
.520 \\
.521 \\
.522\end{array}$ & $\begin{array}{l}.454 \\
.455 \\
.456 \\
.456 \\
.457\end{array}$ & $\begin{array}{l}. \\
.390 \\
.390 \\
.391 \\
.392 \\
.393\end{array}$ & $\begin{array}{l}.357 \\
.358 \\
.358 \\
.359 \\
.360\end{array}$ & $\begin{array}{l}.325 \\
.325 \\
.326 \\
.326 \\
.327\end{array}$ & $\begin{array}{l}.292 \\
.292 \\
.293 \\
.294 \\
.294\end{array}$ & $\begin{array}{l}.259 \\
.260 \\
.260 \\
.261 \\
.261\end{array}$ & $\begin{array}{l}.226 \\
.227 \\
.227 \\
.228 \\
.228\end{array}$ & $\begin{array}{r}195 \\
.195 \\
.196 \\
.396 \\
.196\end{array}$ & $\begin{array}{l}.163 \\
.164 \\
.164 \\
.164 \\
.164\end{array}$ & $\begin{array}{l}.130 \\
.130 \\
.131 \\
.131 \\
.131\end{array}$ & $\begin{array}{r}.098 \\
.098 \\
.098 \\
.099 \\
.099\end{array}$ & $\begin{array}{l}1,450 \\
1,460 \\
1,470 \\
1,480 \\
1,490\end{array}$ \\
\hline $\begin{array}{l}.786 \\
.787 \\
.788 \\
.789 \\
.791\end{array}$ & $\begin{array}{l}.720 \\
.722 \\
.723 \\
.724 \\
.725\end{array}$ & $\begin{array}{l}.655 \\
.656 \\
.657 \\
.658 \\
.659\end{array}$ & $\begin{array}{l}.588 \\
.589 \\
.590 \\
.591 \\
.592\end{array}$ & $\begin{array}{r}.523 \\
.524 \\
.525 \\
.525 \\
.526\end{array}$ & $\begin{array}{l}.457 \\
.458 \\
.459 \\
.460 \\
.461\end{array}$ & $\begin{array}{l}.394 \\
.394 \\
.395 \\
.395 \\
.396\end{array}$ & $\begin{array}{l}.360 \\
.361 \\
.361 \\
.362 \\
.362\end{array}$ & $\begin{array}{l}.327 \\
.328 \\
.328 \\
.329 \\
.329\end{array}$ & $\begin{array}{l}.294 \\
.295 \\
.295 \\
.296 \\
.296\end{array}$ & $\begin{array}{l}.262 \\
.262 \\
.262 \\
.263 \\
.263\end{array}$ & $\begin{array}{r}.229 \\
.229 \\
.230 \\
.230 \\
.230\end{array}$ & $\begin{array}{l}.196 \\
.197 \\
.197 \\
.197 \\
.197\end{array}$ & $\begin{array}{l}.164 \\
.165 \\
.165 \\
.165 \\
.165\end{array}$ & $\begin{array}{l}.131 \\
.132 \\
.132 \\
.132 \\
.132\end{array}$ & $\begin{array}{l}.099 \\
.099 \\
.099 \\
.099 \\
.100\end{array}$ & $\begin{array}{l}1,500 \\
1,510 \\
1,520 \\
1,530 \\
1,540\end{array}$ \\
\hline $\begin{array}{r}.792 \\
.793 \\
.795 \\
.796 \\
.797 \\
.798\end{array}$ & $\begin{array}{r}.726 \\
.727 \\
.728 \\
.729 \\
.730 \\
.731\end{array}$ & $\begin{array}{l}.660 \\
.661 \\
.662 \\
.663 \\
.664 \\
.665\end{array}$ & $\begin{array}{l}.594 \\
.595 \\
.596 \\
.597 \\
.598 \\
.598\end{array}$ & $\begin{array}{l}.527 \\
.528 \\
.529 \\
.530 \\
.531 \\
.531\end{array}$ & $\begin{array}{l}.462 \\
.462 \\
.463 \\
.464 \\
.465 \\
.465\end{array}$ & $\begin{array}{l}.396 \\
.397 \\
.397 \\
.398 \\
.399 \\
.399\end{array}$ & $\begin{array}{l}.363 \\
.364 \\
.364 \\
.365 \\
.365 \\
.366\end{array}$ & $\begin{array}{l}.330 \\
.330 \\
.331 \\
.331 \\
.332 \\
.332\end{array}$ & $\begin{array}{l}.296 \\
.297 \\
.297 \\
.298 \\
.298 \\
.299\end{array}$ & $\begin{array}{l}.263 \\
.264 \\
.264 \\
.264 \\
.265 \\
.266\end{array}$ & $\begin{array}{l}.231 \\
.231 \\
.231 \\
.232 \\
.232 \\
.233\end{array}$ & $\begin{array}{r}199 \\
.199 \\
.199\end{array}$ & $\begin{array}{l}.165 \\
.166 \\
.166 \\
.166 \\
.166 \\
.166\end{array}$ & $\begin{array}{l}.133 \\
.133 \\
.133 \\
.133 \\
.133 \\
.133\end{array}$ & $\begin{array}{l}.100 \\
.100 \\
.100 \\
.100 \\
.100 \\
.100\end{array}$ & $\begin{array}{l}1,550 \\
1,560 \\
1,570 \\
1,580 \\
1,590 \\
1,600\end{array}$ \\
\hline
\end{tabular}

\section{STANDING COMMITTEE}

64. The following individuals comprise the membership of the standing committee, which is to review, prior to circulation for acceptance, revisions proposed to keep the standard abreast of progress. Comment concerning the standard and suggestions for revision may be addressed to any member of the committee or to the Commodity Standards Division, National Bureau of Standards, which acts as secretary for the committee.

\section{Manufacturers:}

\section{George L. Harberger, Chairman}

E. L. Broderick, Institute of Heating Research, American Radiator \& Standard Sanitary Corp., 675 Bronx River Road, Yonkers 4, N. Y.

T. D. Casserly, Manufacturing Division, Weil-McLain Co., Michigan City, Ind.

A. A. Emrick, United States Radiator Corp., 1500 United Artists Bldg., Detroit 31, Mich.

V. A. GOOD, Burnham Boiler Corp., Irvington, N. Y.

George L. Harberger, The Eastern Foundry Co., Boyertown, Pa.

\section{Distributors:}

J. V. Brennan, Sears Roebuck \& Co., Chicago 7, Ill.

Harry M. Hart, 1048 West Van Buren St., Chicago, Ill. (Representing Heating, Piping \& Air Conditioning Contractors National Association.)

W. D. Howard, Heating Division, Crane Co., 836 S. Michigan Ave., Chicago 5, Ill. (Representing The Central Supply Association.)

Logan M. Schilb, Chicago Laboratories, Montgomery Ward \& Co., Chicago 10, Ill.

Frederick Waterman, Decatur-Hopkins Co., 93 Berkeley St., Boston, Mass. (Representing New England Hardware Dealers Association.) 


\section{Consumers:}

Arthur R. Geiger, Corps of Engineers, Department of the Army, Washington 25 , D. C.

Howard Griffith Hall, 130 W. Hamilton St., Baltimore 1, Md. (Representing The American Institute of Architects.)

Mrs. Charlotte Payne, National Council of Women of the U. S., 501 Madison Ave., New York 22, N. Y.

R. K. Thulman, Federal Housing Administration, Washington 25, D. C.

\section{Laboratories and general interests:}

R. S. Dill, National Bureau of Standards, Washington 25, D. C.

R. C. Johnson, Anthracite Institute, Wilkes-Barre, Pa.

Bertrand A. Landry, Battelle Memorial Institute, Columbus 1, Ohio.

L. E. Seeney, College of Technology, University of New Hampshire, Durham, N. H.

Ralph A. Sherman, Battelle Memorial Institute, Columbus 1, Ohio. (Representing Committee of Ten-Coal \& Heating Industries, and Bituminous Coal Research, Inc.)

C. C. Wright, Division of Fuel Technology, Pennsylvania State College, State College, Pa.

\section{HISTORY OF PROJECT}

65. On August 3, 1942, the Federal Housing Administration requested the cooperation of the National Bureau of Standards in the establishment of a commercial standard for testing and rating hand-fired hot-water-supply boilers. Pursuant to this request, a preliminary conference of representatives of interested laboratories and Government agencies was held on October 16, 1942, at the Bureau, to review and adjust tentative drafts of the proposed standard.

66. The adjusted draft was circulated on October 26 and 27 to leading manufacturers, distributors, and users for comment and recommendations. In response, a number of constructive suggestions were received, and incorporated in the draft.

67. A general conference, to which interested producers, distributors, users, and testing laboratories were invited to consider the proposed standard, was held at the Departmental Auditorium, Washington, D. C., on December 4, 1942. The recommended standard adopted by this conference was circulated to those concerned on December 29, 1942, for written acceptance.

68. During 1943 the proposed standard was revised twice, as a result of further recommendations offered, particularly by the Institute of Boiler and Radiator Manufacturers and by the Anthracite Industries Laboratory. Following each revision, an adjusted draft was circulated to the trade for consideration and approval.

69. On October 27, 1944, a conference of manufacturer members of the standing committee, held at Pittsburgh, Pa., recommended that a code for the testing of hand-fired boilers, in the course of preparation by the Institute of Boiler and Radiator Manufacturers, be extended to cover hot-water-supply boilers down to the smallest sizes, and that this code, when completed, be used as a basis for further revision of the recommended commercial standard. In line with this recommendation, a draft submitted by the Institute, after minor adjustments, was approved by the standing committee, and circulated on December 26, 1946, to the entire trade for written acceptance 
70. Following receipt of acceptances estimated to represent a satisfactory majority, the establishment of the commercial standard, identified as CS145-47, was announced on November 26, 1947.

\section{EFFECTIVE DATE}

71. Having been passed through the regular procedure of the Commodity Standards Division, and approved by the acceptors hereinafter listed, this commercial standard was issued by the United States Department of Commerce, to become effective for new production from December 1, 1948.

Edwin W. Ely,

Chief, Commodity Standards Division 


\section{ACCEPTANCE OF COMMERCIAL STANDARD}

If acceptance has not previously been filed, this sheet properly filled in, signed, and returned will provide for the recording of your organization as an acceptor of this commercial standard.

Date

Commodity Standards Division, National Bureau of Standards, Washington $25, \mathrm{D}$. C.

Sirs:

We believe that the Commercial Standard CS145-47 constitutes a useful standard of practice, and we individually plan to utilize it as far as practicable in the

production $^{1} \quad$ distribution $^{1} \quad$ purchase $^{1}$ testing ${ }^{1}$

of hand-fired hot-water-supply boilers.

We reserve thè right to depart from it as we deem advisable.

We understand, of course, that only those articles which actually comply with the standard in all respects can be identified or labeled as conforming thereto.

Signature of authorized officer

(Kindly typewrite or print the following lines)

Name and title of above officer

Organization

(Fill in exactly as it should be listed)

Street address

City, zone, and State

1 Underscore which one. Please see that separate acceptances are filed for all subsidiary companies and affiliates which should be listed separately as acceptors. In the case of related interests, trade associations, trade papers, etc., desiring to record their general support, the words "General support" should be added after the signature. 


\section{TO THE ACCEPTOR}

The following statements answer the usual questions arising in connection with the acceptance and its significance:

1. Enforcement.-Commercial standards are commodity specifications voluntarily established by mutual consent of those concerned. They present a common basis of understanding between the producer, distributor, and consumer and should not be confused with any plan of governmental regulation or control. The United States Department of Commerce has.no regulatory power in the enforcement of their provisions, but since they represent the will of the interested groups as a whole, their provisions through usage soon become established as trade customs, and are made effective through incorporation into sales contracts by means of labels, invoices and the like.

2. The acceptor's responsibility.-The purpose of commercial standards is to establish for specific commodities, nationally recognized grades or consumer criteria, and the benefits therefrom will be measurable in direct proportion to their general recognition and actual use. Instances will occur when it may be necessary to deviate from the standard and the signing of an acceptance does not preclude such departures; however, such signature indicates an intention to follow the commercial standard where practicable, in the production, distribution, or consumption of the article in question.

3. The Department's responsibility.-The major function performed by the Department of Commerce in the voluntary establishment of commercial standards on a Nation-wide basis is fourfold: first, to act as an unbiased coordinator to bring all interested parties together for the mutually satisfactory adjustment of trade standards; second, to supply such assistance and advice as past experience with similar programs may suggest; third, to canvass and record the extent of acceptance and adherence to the standard on the part of producers, distributors, and users; and fourth, after acceptance, to publish and promulgate the standard for the information and guidance of buyers and sellers of the commodity.

4. Announcement and promulgation.-When the standard has been endorsed by a satisfactory majority of production or consumption in the absence of active, valid opposition, the success of the project is announced. If, however, in the opinion of the standing committee or the Department of Commerce, the support of any standard is inadequate, the right is reserved to withhold promulgation and publication. 


\section{ACCEPTORS}

The organizations and individuals listed below have accepted this standard as their standard of practice in the production, distribution, and use of handfired hot-water-supply boilers. Such endorsement does not signify that they may not find it necessary to deviate from the standard, nor that producers so listed guarantee all of their products in this field to conform with the requirements of this standard. Therefore, specific evidence of conformity should be obtained where required.

\section{ASSOCIATIONS}

(General Support)

American Association of Engineers, Chicago, Ill.

American Homemakers Association, Lorain, Ohio.

Building Officials Conference of America, Inc., Washington, D. C.

Consumers Union of United States, Inc., New York, N. Y.

Heating, Piping \& Air Conditioning Contractors D. C. Association, Inc., Washington, D. C.

Heating, Piping \& Air Conditioning Contractors National Association, New York, N. Y.

National Association of Master Plumbers, New York, N. Y.

Rocky Mountain Coal Mining Institute, The, Denver, Colo.

Western Plumbing Officials Association, Los Angeles, Calif.

\section{FIRMS AND OTHER INTERESTS}

Aimes Engineering Co., Cleveland, Ohio.

American Boiler \& Foundry Co., The, Milan, Mich.

American Radiator \& Standard Sanitary Corp., Pittsburgh, $\mathrm{Pa}$.

Armour Research Foundation, Chicago, Ill.

Automatic Heat, Inc., Philadelphia, Pa.

Battelle Memorial Institute, Fuels Division, Columbus, Ohio.

Bayonne Steel Products Co., Newark, N. J.

Better Living Co., Jackson, Miss.

Bon Heating $\mathrm{Co}$, Milwaukee, Wis.

Boyd Engineering Co., El Paso, Tex.

Bull, Ralph N., Sparta, N. J.

Burnham Boiler Corp., Irvington, N. Y.

Canfield Supply Co., Kingston, N. Y.

Cedar Rapids Pump \& Supply Co., Cedar Rapids, Iowa.

Chandler Co., Cedar Rapids, Iowa.

Cincinnati, City of, Department of Purchasing, Cincinnati, Ohio.

Coal Heat Magazine, Chicago, Ill. (General support.)

Columbia Pipe \& Supply Co., Chicago, Ill

Corrivequx, F., Home \& Industrial Service, Schenectady, N. Y.

Crane Co., Chicago, Ill.

Dallman Supply Co., San Francisco, Calif.

Daly, M. J., \& Sons, Inc., Waterbury, Conn.

Dalziel Plumbing Supplies, San Francisco, Calif.

Delaware, Lackawanna \& Western Coal Co., The, New York, N. Y.

Detroit, University of, Detroit, Mich.

District Engineering Co., Washington, D. C

Eastern Foundry Co., The, Boyertown, $\mathrm{Pa}$.

Edmonds, James R., Jr., Baltimore, Md.

Electrical Testing Laboratories, Inc., New York, N. Y.
Ellis, Sol, \& Sons, Inc., Chicago, Ill.

Emery Industries, Inc., Cincinnati, Ohio.

Fleck Co., Camden, N. J.

Glauber, Sam S., Inc., New York, N. Y.

Graves Engineering Co., Nashville, Tenn. (General support.)

Gregory, J. M., Heating \& Plumbing Co., Jacksonville, Fla.

Harley, Ellington \& Day, Inc., Detroit, Mich.

Heating Supply Co., Inc., Rochester, N. Y.

Hermitage Engineering Co., Nashville, Tenn.

International Heater Co., Utica, N. Y.

Iron Fireman Eales Corp., Washington, D. C.

Kohler Co., Kohler, Wis.

Koller Bros. Co., The, Cleveland, Ohio.

Master Plumber \& Heating Contractor Magazine, Brooklyn, N. Y. (General support.)

McDermott Water Heaters, Inc., Trenton, N. J.

Mid-States Industrial Corp., Rockford, Ill.'

Minneapolis, City of, Engineering Department, Minneapolis, Minn.

Minnesota, University of, Minneapolis, Minn.

Monroe Air Conditioning Co., Inc., Rochester, N. Y.

Montgomery Ward, Chicago, Ill.

Moran, Clifford R., Plumbing \& Heating Service, Highland Park, Ill.

Mormile Wholesale Plumbing \& Heating Supplies, Amsterdam, N. Y.

Mutual Heating \& Plumbing Co., Buffalo, N. Y.

National Radiator $\mathrm{Co}$., The, Johnstown, $\mathrm{Pa}$

Nebraska, University of, Agricultural Experiment Station, Lincoln, Nebr.

New York Testing Laboratcries, Inc., New York, N. Y.

Northern Heating \& Plumbing Co., Inc., Laconia, N. H.

Oklahoma, University of, Norman, Okla.

Orange Memorial Hospital, Orange, N. J. (General support.)

Oviatt Plumbing \& Heating Distributing Co., Inc., Troy, N. Y.

Pacific Coast Heating \& Appliance Co., Portland, Oreg.

Pacific Supply Cooperative, Walla Walla, Wash.

Peninsular Stove Co., Detroit, Mich.

Pennsylvania Engineering Co., Philadelphia, Pa.

Pennsyivania Hospital, Philadelphia, Pa.

Pennsylvania State College, The, School of Mineral Industries, State College, $\mathrm{Pa}$.

Rochester, City of, Board of Education, Rochester, N. Y.

Rudy Furnace Co., Dowagiac, Mich.

Sears, Roebuck \& Co., Chicago, Ill.

Stewart, C., \& Son, Inc., Worcester, Mass.

Swarthmore Heating Service, Swarthmore, Pa.

Technical Advisory Service, Kew Gardens Hills, Long Island, N. Y. (General support.)

Tennessee, University of, Engineering Experiment Station, Knoxville, Tenn.

Thatcher Furnace Co., Garwood, N. J. 
Thomson-Diggs Co., The, Sacramento, Calif.

United States Radiator Corp., Detroit, Mich.

United States Testing Co., Inc., Hoboken, N. J. (General support.)

Virginia Polytechnic Institute, Blacksburg, Va. (General support.)

Weil-MICLain Co., Michigan City, Ind.

Weiss Heating \& Plumbing Co., The, Cleveland, Ohio.

Wiedcbusch Plumbing \& Heating Co., Fairmont, W. Va.

Worthington, Gcorge, Co., The, Cleveland, Ohio.

\section{U. S. GOVERNMENT}

Agriculture, Department of, Division of Purchase, Sales \& Traffic, Washington, D. C.

Federal Housing Administration, Washington, D. C.

Federal Works Agency, Public Buildings Adminis. tration, Washington, D. C. (General support.) Interior Department, Bureau of Mines, Washing ton, D. C.

Interior Department, National Capital Parks, Washington, D. C. 


\section{COMMERCIAL STANDARDS}

CS No.

0-40. Commercial standards a

1-42. Clinical thermometers (third edition).

2-30. Mopsticks.

3-40. Stoddard solvent (third edition).

4-29. Staple porcelain (all-clay) plumbing fixtures.

5-46. Pipe nipples; brass, copper, steel, and wrought-iron (second edition).

6-31. Wrought-iron pipe nipples (second edition). Superseded by CS5-46.

7-29. Standard weight malleable iron or steel screwed unions.

8-41. Gage blanks (third edition).

9-33. Builders' template hardware (second edition).

10-29. Brass pipe nipples. Superseded by CS5-46.

11-41. Moisture regains of cotton yarns (second edition)

12-40. Fuel oils (fifth edition)

13-44. Dress patterns (fourth edition).

14-43. Boys' button-on waists, shirts, junior and sport shirts (made from woven fabrics) (third edition)

15-46. Men's pajama sizes (made from woven fabrics) (third edition).

16-29. Wallpaper.

17-47. Diamond core drill fittings (fourth edition).

18-29. Hickory golf shafts.

19-32. Foundry patterns of wood (second edition)

20-47. Staple vitreous china plumbing fixtures (fourth edition).

21-39. Interchangeable ground-glass joints, stopcocks, and stoppers (fourth edition).

22-40. Builders' hardware (nontemplate) (second edition).

23-30. Feldspar.

24-43. Screw threads and tap-drill sizes.

25-30. Special screw threads. Superseded by CS24-43.

26-30. Aromatic red cedar closet lining.

27-36. Mirrors (second edition).

28-46. Cotton fabric tents, tarpaulins, and covers (second edition).

29-31. Staple seats for water-closet bowls

30-31. Colors for sanitary ware.

31-38. Wood shingles (fourth edition).

32-31. Cotton cloth for rubber and pyroxylin coating.

33-43. Knit underwear (exclusive of rayon) (second edition).

34-31. Bag, case, and strap leather

35-47. Hardwood plywood (third edition).

36-33. Fourdrinier wire cloth (second edition).

37-31. Steel bone plates and screws.

38-32. Hospital rubber sheeting.

39-37. Wool and part wool blankets (second edition). (Withdrawn as commercial stand. ard, July 14, 1941).

40-32. Surgeons' rubber'gloves.

41-32. Surgeons' latex gloves.

42-43. Structural fiber insulating board (third edi tion).

43-32. Grading of sulphonated oils.

44-32. Apple wraps.

45-47. Douglas fir plywood (seventh edition).

46-40. Hosiery lengths and sizes (third edition)

47-34. Marking of gold-filled and rolled-gold-plate articles other than watcheases.

48-40. Domestic burners for Pennsylvania anthracite (underfeed type) (second edition).

49-34. Chip board, laminated chip board and mis cellaneous boards for bookbinding purposes.

50-34. Binders board for bookbinding and other purposes.
CS No.

Item

51-35. Marking articles made of silver in com bination with gold.

52-35. Mohair pile fabrics (100-percent mohair plain velvet, 100-percent mohair plain frieze, and 50-percent mohair plain frieze).

53-35. Colors and finishes for cast stone.

54-35. Mattresses for hospitals.

55-35. Mattresses for institutions.

56-41. Oak flooring (second edition).

57-40. Book cloths, buckrams, and impregnated fabrics for bookbinding purposes except library bindings (second edition).

58-36. Woven elastic fabrics for use in overalls (overall elastic webbing).

59-44. Textiles-testing and reporting (fourth edition).

60-48. Hardwood dimension lumber (second edition).

61-37. Wood-slat venetian blinds

62-38. Colors for kitchen accessories.

63-38. Colors for bathroom accessories.

64-37. Walnut veneers.

65-43. Methods of analysis and of reporting fiber composition of textile products (second edition).

66-38. Marking of articles made wholly or in part of platinum

67-38. Marking articles made of karat gold.

68-38. Liquid hypochlorite disinfectant, deodorant, and germicide.

69-38. Pine oil disinfectant.

70-41. Phenolic disinfectant (emulsifying type) (second edition) (published with CS71-41)

71-41. Phenolic disinfectant (soluble type) (second edition) (published with CS70-41).

72-38. Household insecticide (liquid spray type).

73-45. Old growth Douglas fir standard stock doors (third edition).

74-39. Solid hardwood wall paneling

75-42. Automatic mechanical draft oil burners designed for domestic installations (second edition)

76-39. Hardwood interior trim and molding

77-40. Sanitary cast-iron enameled ware.

78-40. Ground-and-polished lenses for sun glasses (second edition) (published with CS79-40)

79-40. Blown, drawn, and dropped lenses for sun glasses (second edition) (published with CS78-40).

80-41. Electric direction signal systems other than semaphore type for commercial and other vehicles subject to special motor vehicle laws (after market).

81-41. Adverse-weather lamps for vehicles (after market)

82-41. Inner-controlled spotlamps for vehicles (after market).

83-41. Clearance, marker, and identification lamps for vehicles (after market)

84-41. Electric tail lamps for vehicles (after market)

85-41. Electric license-plate lamps for vehicles (after market).

86-41. Electric stop lamps for vehicles (after market).

87-41. Red electric warning lanterns.

88-41. Liquid-burning flares.

89-40. Hardwood stair treads and risers.

90- (Reserved for power shovels and cranes.)

91-41. Factory-fitted Douglas fir entrance doors.

92-41. Cedar, cypress, and redwood tank stock lumber.

93-41. Portable electric drills (exclusive of high frequency).

94-41. Calking lead.

95-41. Lead pipe. 
CS No.

96-41. Lead traps and bends.

97-42. Electric supplementary driving and passing lamps for vehicles (after market).

98-42. Artists' oil paints.

99-42. Gas floor furnaces-gravity circulating type.

100-47. Porcelain-enameled steel utensils (third edition).

101-43. Flue-connected oil-burning space heaters equipped with vaporizing pot-type burners.

102- . (Reserved for Diesel and fuel-oil engines.)

$103-42$. Cotton and rayon velour (jacquard and plain).

104-46. Warm-air furnaces equipped with vaporizing pot-type oil burners (second edition).

105-43. Mineral wool; loose granulated, or felted form, in low-temperature installations.

106-44. Boys' pajama sizes (woven fabrics) (second edition).

107-45. Commercial electric-refrigeration condensing units (second edition). (Withdrawn as commercial standard September 4, 1947.)

108-43. Treading automobile and truck tires.

109-44. Solid-fuel-burning forced-air furnaces.

110-43. Tire repairs-vulcanized (passenger, truck, and bus tires).

111-43. Earthenware (vitreous-glazed) plumbing fixtures.

112-43. Homogeneous fiber wallboard.

113-44. Oil-burning floor furnaces equipped with vaporizing pot-type burners.

114-43. Hospital sheeting for mattress protection.

115-44. Porcelain-enameled tanks for domestic use.

116-44. Bituminized-fibre drain and sewer pipe.

117-44. Mineral wool; blankets, blocks, insulating cement, and pipe insulation for heated industrial equipment.

118-44. Marking of jewelry and novelties of silver.

(E) 119-45.1 Dial indicators (for linear measurements).
CS No.

Iten

120-46. Standard stock ponderosa pine doors (second edition).

121-45. Women's slip sizes (woven fabrics).

122-45. Western hemlock plywood.

123-45. Grading of diamond powder.

(E) 124-45.1 Master disks.

125-47. Prefabricated homes (second edition)

126-45. Tank mounted air compressors.

127-45. Self-contained mechanically refrigerated drinking water coolers.

128-45. Men's sport shirt sizes-woven fabrics (other than those marked with regular neckband sizes).

129-47. Materials for safety wearing apparel (second edition).

130-46. Color materials for art education in schools.

131-46. Industrial mineral wool products, all typestesting and reporting.

132-46. Hardware cloth.

133-46. Woven wire netting.

134-46. Cast aluminum cooking utensils (metal composition).

135-46. Men's shirt sizes (exclusive of work shirts)

136-46. Blankets for hospitals (wool, and wool and cotton).

137-46. Size measurements for men's and boys' shorts (woven fabrics).

138-47. Insect wire screening.

139-47. Work gloves.

140-47. Testing and rating convectors.

141-47. Sine bars, blocks, plates, and fixtures.

142-47. Automotive lifts.

143-47. Standard strength and extra strength perforated clay pipe.

144-47. Formed metal porcelain enameled sanitary ware.

145-47. Testing and rating hand-fired hot-water-supply boilers.

146-47. Gowns for hospital patients.

147-47. Colors for molded urea plastics.

Notice.-Those interested in commercial standards with a view toward accepting them as a basis of everyday practice may secure copies of the above standards, while the supply lasts, by addressing the Commodity Standards Division, National Bureau of Standards, Washington 25, D. C.

1 Where "(E)" precedes the CS number, it indicates an emergency commercial standard, drafted under war conditions with a view toward early revision. 